\title{
The Metal Casting Traditions of South Asia: Continuity and Innovation
}

\author{
Paul T Craddock*
}

(Received 8 October 2014)

\begin{abstract}
This paper, after outlining some of the more significant milestones through seven millennia of casting achievement and the historic literary sources, will concentrate on the more recent continuing traditional technologies of South Asia. The paper will conclude with an assessment of our present understanding of early casting methods elsewhere, notably those of Egypt, Greece and Rome.
\end{abstract}

Key words: Brass, Bronze, Crucible, India, Lost wax, Metalworking, Nepal.

\section{INTRODUCTION}

As Reeves (1962, pps.2, 14-15) remarked, South Asia from the Himalayas to Sri Lanka was the ideal place to study the history of casting practices. For not only are there an abundance of surviving castings dating back to the $5^{\text {th }}$ millennium BC but there is an extensive early literature often going into surprising practical detail, unmatched anywhere else in the world before the Post Medieval Period. Useful though these information sources are, it is the surviving traditional foundries of South Asia that provide the most invaluable insight into the social, economic and technical aspects of metal casting in the past. Certainly, an understanding of the present day craftsmen and their working methods can lead to a better understanding of the practices of the past based just on the examination of the surviving castings, as is necessarily the case in many other parts of the world.

There were some records made in Colonial times of metal casting communities, such as those of Francis Buchanan in 1809-10 of the bidri makers of Purnia, now in Bihar (Jackson 1928), and early but important works such as those of Neogi (1917). Post independence the traditional casting communities have been recorded in meticulous detail by the Indian Census, such as that made for central India (Nambiar 1964). These have provided a wealth of information on all aspects of their life and work, backed up by studies such as those of Mehta (1960), Krishnan (1976), Mukherjee (1978) and Chakrabarti and Lahiri (1996), together with more specific works such as those of Reeves (1962), Horne (1987), Reedy (1987), on the tribal casters; Levy et al (2008) for the major image casters of Swamimalli, Tamil Nadu; and Lo Bue (1981), Dagyab (1977, Chap. 20, pp.50-1), de Labriffe (1973) and Alsop and Charlton (1973) for the Newari casters of Nepal.

\section{Historic Overview of Casting}

It is likely that the majority of early tools and weapons, such as those described and illustrated by Chakrabarti and Lahiri (1996, Chapt. 3) will have been cast in relatively simple single or double piece moulds, usually of ceramic, but sometimes of stone. It might be thought that the

*Department of Conservation and Science, The British Museum, London, WC1B 3DG; email: paulcraddock74@btinternet.com 
more sophisticated process of lost wax casting would appear relatively late, but in some regions of the world such as South Asia it has a very long history (Hunt 1980; Davey 2009), back almost to the inception of metallurgy itself ${ }^{1}$. It is claimed that already by the $5^{\text {th }}$ millennium BC the lost wax process was being used to cast armlets at the prehistoric settlement at Mehrgarh, now in Pakistan, making them the earliest lost wax artefacts known (Davey 2009). The armlets are of copper to which lead had been added. This in itself is of some significance suggesting deliberate alloying even at this early date, as quite small quantities of lead in a copper alloy can greatly increase the fluidity of the molten metal, and thus its ability to flow, filling confined and intricate spaces in a mould. ${ }^{2}$ Lost wax castings are again encountered, somewhat later at the end of the fifth millennium BC, at Shahi-Tump, also in Pakistan (Mille et al. 2004).

Moving onto the major early civilisations of north India, the Harappans, it is likely that the majority of their copper alloy tools and weapons, the flat axes, etc. were cast in single or two-piece clay moulds, but some pieces such as the famous dancing girl are almost certainly lost wax castings (Fig. 1). A number of simple but heavy cast copper vessels are known. These could have been produced by piece moulding, lost wax or even sand cast. $^{3}$ Both copper and bronze were used

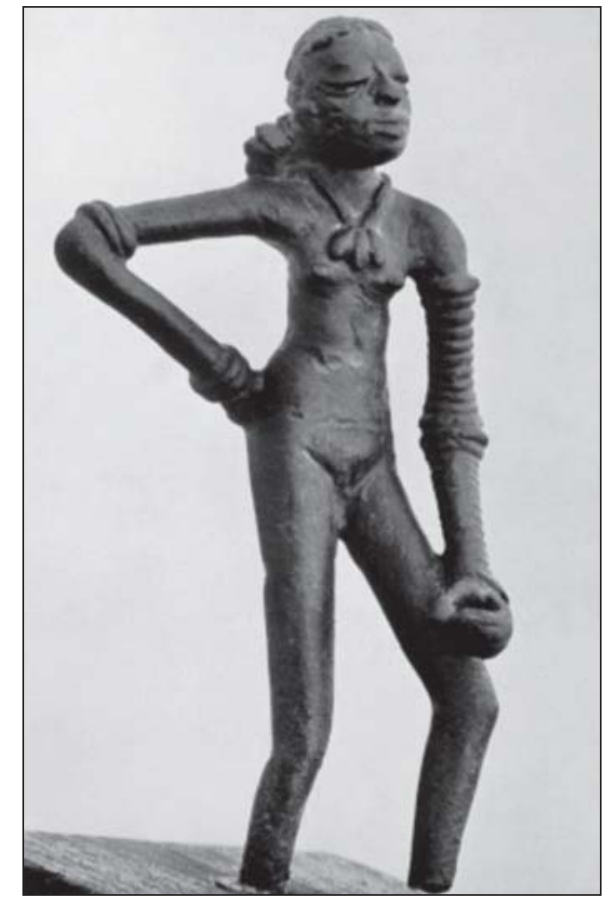

Fig. 1. The dancing girl from Mohenjo-daro. Harappan, 2500 BC. Lost wax copper alloy casting. (Photogravure 1938, National Museum Delhi)

(summarised in Chakrabarti and Lahiri 1996, pp.36-61).

The heavy, often clumsy and clearly unfinished copper castings that form the bulk of the material in the enigmatic copper hoards of the Doab and Bengal (Yule 1989 \& 1997) are all likely to have been cast in simple one or two-piece moulds ${ }^{4}$.

\footnotetext{
${ }^{1}$ In the Middle East and West Africa lost wax casting was almost the first casting technique used, whereas in other parts of the world, notably China and Western Europe it was only adopted much later. In fact the lost wax process has never been a common technique in Europe as it has been in India. It seems that the choice of technique was as much a cultural decision as technical, for example the differing methods adopted by the various Indian traditional casters, such as those in Madhya Pradesh, often working in close proximity to one another (Reeves1962, pp.86-7).

${ }^{2}$ It is noticeable throughout the long history of lost wax casting how often the alloys used were more heavily leaded than those used for simpler castings, both in South Asia (as discussed below) and elsewhere, notably in the Greco-Roman world (Craddock 1985).

${ }^{3}$ Somewhat similar heavy cast vessels, but now of brass, are still cast by the lost wax process in Kerala and in Nepal (see below and Gajurel and Vaidya 1984, pp.42-4); and by a combination of piece moulding and sand casting at Mirzapur, Uttar Pradesh (see below and Prakash 1998).

${ }^{4}$ The rather limited range of shapes coupled with their unfinished state has led to suggestions that many of them had only a ritual function, or were actually ingots (Yule 1985), even perhaps functioning as a precursor to a currency. Most are of copper but some have extraordinarily high iron contents that would have rendered them unfit for any practical use (Hauptmann 1989; Hughes 1989), such as has been recorded in some early coinage systems where weight was the main consideration (Craddock and Meeks 1987). For example, Hegde (1975) found approximately $20 \%$ of iron in a group of Paunar copper coins dated to the $7^{\text {th }}$ century AD of the Deccani Vishnu-Kundir dynasty.
} 
Overall in South Asia, through prehistory, the Mauryan Empire and beyond, relatively few lost wax castings have been found and it seems that their production was rather infrequent, certainly when compared with later periods. This was to change dramatically with the rise of both Buddhism and Hinduism in which the worship of idols played a significant part. From the Gandharan period on images were produced in prodigious numbers. Initially these were mainly of bronze but were increasingly replaced by brass. The figures were usually lost wax castings, initially mainly solid castings, but soon joined by hollow castings, which became prevalent particularly for the larger figures (see below). By far the largest surviving figure is the famous Buddha found at Sultanganj, near to Nalanda, in Bihar, probably dated to the $6^{\text {th }}$ or $7^{\text {th }}$ century AD (Fig. 2). This enormous figure is $2.23 \mathrm{~m}$ tall and weighs over $500 \mathrm{~kg}$ (including core material). It is hollow and was apparently cast in a number of sections. It is of an impure copper containing several percent of iron (N. Seeley per. com) $)^{5}$.

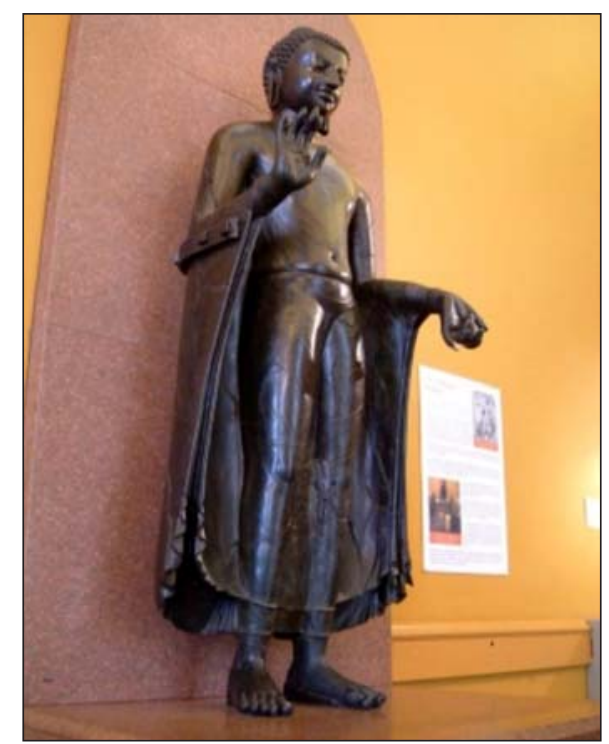

Fig. 2. The Buddha from Sultanganj, Bihar. Gupta-Pala, $5^{\text {th }}$ $7^{\text {th }}$ century AD. Lost wax copper hollow casting. (Birmingham Museum and Art Gallery.)
The Sultanganj Buddha is apparently unique, but in the south of India the casting of major figures developed in the Pala and Chola cultures from about the $9^{\text {th }}$ century AD onwards. These were made by the direct lost wax process and were usually solid. Major bronze casting has persisted through the centuries down to the present at centres such as Swamimalli in the Thanjavur District of Tamil Nadu. Now, many of the larger figures are hollow cast, especially those cast by the non-hereditary entrepreneur-owned foundries, although the hereditary sthapathi foundries still mainly produce solid castings (Levy et al., 2008). The early figures were of copper or of bronze with just a few percent of tin and sometimes lead as well (Craddock and Hook, 2007). The use of bronze persisted for much longer in the south of India than in the north, and even now zinc only forms a minor component of the alloy along with tin and lead (see footnote 14).

Together with these major imageproducing centres in the north and south of India there are the small scale tribal foundries, often impermanent, throughout much of India, producing a range of products, including images, usually in brass (Reeves 1962, and see below).

\section{BidRI AND THE USE OF SAND CASTING}

The bidri makers (Untracht 1968, pp.13849; Stronge 1985; Lal 1990), sand cast their wares in an alloy of zinc with just a few percent of copper (La Niece and Martin 1987). The castings are patinated to create a deep matt black surface showing off the silver inlay to best advantage.

This is a quintessentially Indian product, relying as it does on the availability of metallic zinc, and production very likely originated at the Birmani capital of Bidar in the Deccan sometime in the $15^{\text {th }}$ or $16^{\text {th }}$ centuries (Yazdami, 1995, p.20)

\footnotetext{
5 This quantity of iron is common in copper smelted by traditional processes before refining and suggests that for some reason the metal was not refined before use. Similar iron contents have been found in contemporary bronze figurines from Nalanda (Lal 1956) and also in the equally famous $8^{\text {th }}$ century, Bodhisattva Tara (Craddock and Hook 2007, Table 2, and see below).
} 


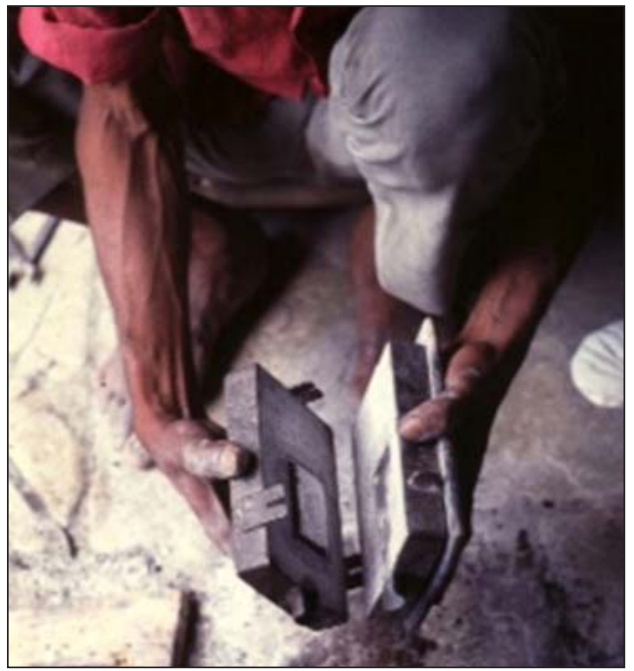

Fig. 3. Sand casting bidri ware. Yacoob Bros, Gunfoundry, Hyderabad 1991. (P. Craddock)

and has traditionally been made there and at Hyderabad as well as further north at Lucknow and Purnea. The process is of considerable interest, not least because it is the only traditional casting process for artistic or prestige items to use the sand casting method (Fig. 3). Unfortunately there are no early descriptions, known early production sites or even early signed pieces, and thus the earlier technical history is uncertain. At the end of the $19^{\text {th }}$ century the process almost became extinct, but was revived in Hyderabad in the 1920's. Subsequently it spread back to a number of sites in the Deccan, using sand casting, and to some extent it has been assumed that this was the traditional method. However, the $19^{\text {th }}$ and early $20^{\text {th }}$ century descriptions differ. Buchanan in his detailed description of bidri-making at Purnea made in 1809/10 (Jackson, 1928, pp.533-5) unequivocally states that the pieces were cast in clay moulds, as does Yazdami (1995, p.20) a century later at Bidar. Mukharji (1886) and Gairola (1956), both claim that the pieces were cast by the lost wax process. This is less likely, given the relatively simple shapes of the typical bidri -ware vessels and boxes, which would be easy to caste in two piece clay moulds, or indeed by sand casting as now.
As noted above sand casting is otherwise unattested as an indigenous process in South Asia, although it seems to have been used by Islamic smiths (La Niece, 2003). The traditional brass founding industries at Mirzapur in Uttar Pradesh, casting domestic pots and pans, use methods with moulds incorporating both clay and sand casting techniques (Prakash, 1998). The technique is claimed to have been introduced by itinerant Moslem metalsmiths over four centuries ago who settled there because of the large deposits of good loamy sand ideal for sand casting. In this process the inner mould is of sand, but the outer mould is formed of a thin layer of clay, tempered with chopped rice straw. The use of clay dispenses with the need for a flask to contain the sand.

Dagyab (1977, pp.50-1) described an interesting Nepalese variant on the sand casting process in which the usual loamy sand is replaced by a fine peaty mud. The process is otherwise very similar to standard sand casting and is used to cast both vessels and figures. The template is impressed into the two frames containing the wet mud and allowed to dry. The two halves are temporarily separated to remove the template, and, after further drying, rejoined with the space inside forming the mould 'like two halves of a peach without the stone’ in Dagyab’s apt simile.

\section{Coins and Mass Production}

Indian coinage, introduced from the mid first millennium BC was of silver and the coins were struck. However at the end of the first millennium BC and for several centuries after copper alloy coins were cast (Sahni, 1945; Mukherjee and Lee, 1988). This is of some importance as the technology employed was very different from other Indian casting technologies. At Rohtak, near Delhi, many thousands of small clay mould fragments were found from which it was possible to reconstruct the multiple piece mould in which up to a hundred coins could be cast simultaneously (Fig. 4). Coin templates were 


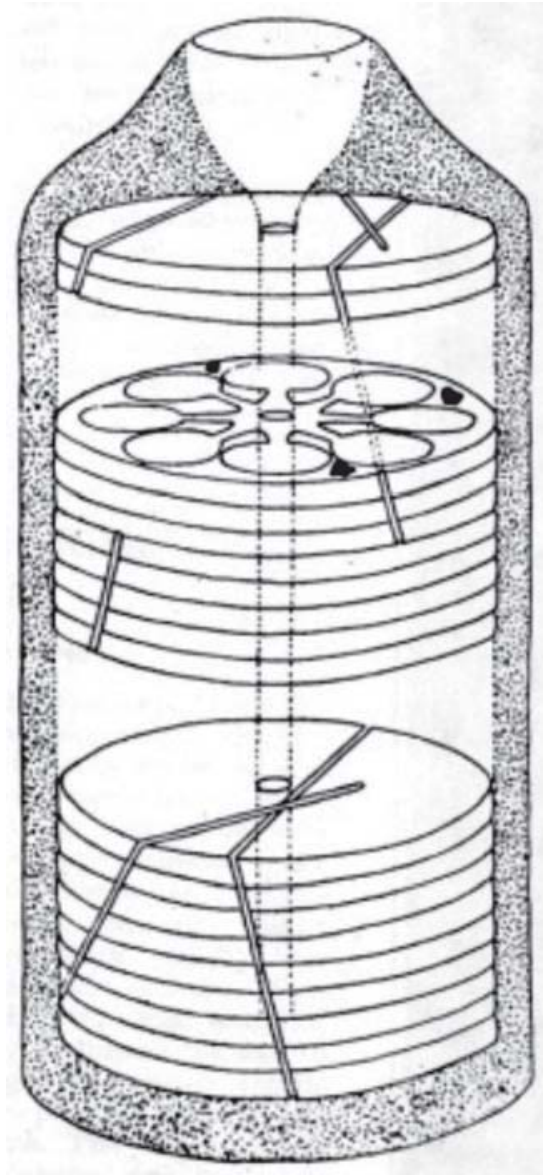

Fig. 4. Reconstruction of a complex piece mould for casting copper coins. Note the 3 black dots, these represent pebbles that were placed between the two halves of each pair of piece moulds, sinking into the soft clay to ensure they located accurately when the two halves were rejoined. (from Sahni 1945)

impressed into a clay disc and then another disc placed on top to create a two-piece mould. Once the impression was made the upper disc was temporarily lifted to remove the template. In the upper surface of the top mould coin templates were again impressed and another clay disc placed over that to create another two- piece mould and the process repeated to create a true stack mould. The discs were then reassembled, placed in a clay cylinder, fired and metal poured down the central space. Stack moulds are not otherwise attested in India, but were common in China for a variety of castings including coins, which were usually of copper alloy (Zhou, 2003). In India cast coinage ceased to be produced in the mid first millennium $\mathrm{AD}$ and with it this rather advanced casting technique.

\section{Cannon}

From about 1500 AD huge cannon and bombards of bronze and brass were cast in South Asia (Balasubramaniam 2008, esp. pps.65-8 \& 90$1)^{6}$. The origins of their production is uncertain, both Turkey and Central Asia have been posited, or just possibly Western Europe, where the casting of very large bronze bells had already been practiced for several centuries (Elphick, 1988). Biringuccio described the European process in his Pirotechnia of 1540 (Smith and Gnudi, 1942, pp.212-59). A model or template of the gun to be cast was made and clay moulded around this in sections so that they could be taken apart and the template removed. They were then reassembled in the casting pit and usually bound around with iron bands (Fig. 5). A clay core was inserted into the mould leaving space for the metal to flow around it. It was obviously essential that the bronze wall of the cannon was of uniform thickness and so the core was held securely in place by metal spacers between the inner wall of mould and the core. The mould was then fired in the pit surrounded by several furnaces in which the metal was being melted. When judged ready the metal would be run from the furnaces into the mould in an orderly sequence ${ }^{7}$. Alternatively if the gun was heavily decorated it might be more convenient to

\footnotetext{
${ }_{6}$ The 'Malik-I-Maidān', Monarch of the Plain, now at Bijapur weighs approximately 55 tons (Neogi 1917), and the great gun at Agra is estimated to have weighed over 30 tons.

7 The dramatic account of the casting of a large mortar at Agra in 1526 given by the Mughal Emperor Babur in the Bābur-nāma (Beveridge 1969, pp.536-47) gives a good description of the arrangements for running the metal into the mould 'Round the mortar mould he (Ustad Ali Quli Khan, Babur's chief gun-founder) had eight furnaces in which were the molten materials. From each furnace, a channel went direct to the mould. When he opened the furnace holes, the molten metal poured like water through all these channels into the mould.'
} 


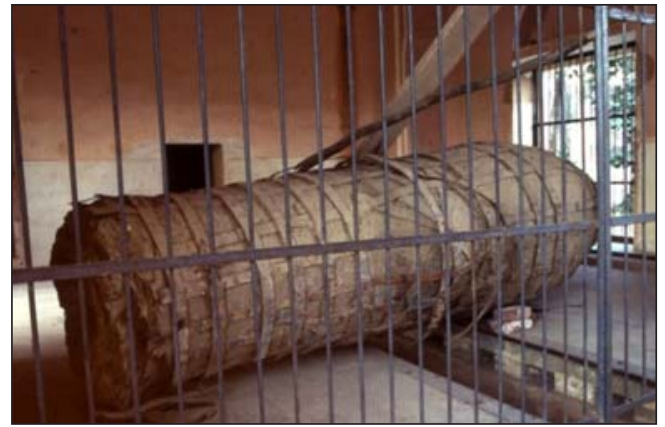

Fig. 5. Complete unused mould for casting cannon, probably $18^{\text {th }}-19^{\text {th }}$ century, at the Jaigarh fort cannon casting foundry. Note the iron bands binding the mould. (P. Craddock, 1984)

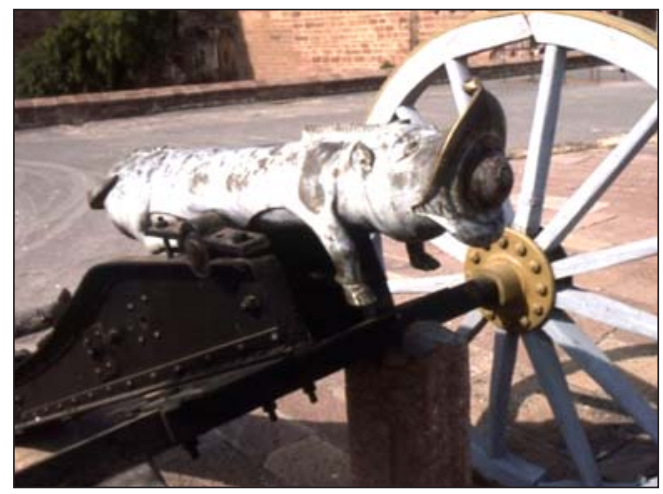

Fig. 6. Cannon in the form of a pig. Lost wax brass casting. Jodphur fort, $18^{\text {th }}$ century. (P. Craddock, 1984)

cast it by the lost wax process (Fig. 6), although this was not common. After casting the core was removed and the chamber of the cannon bored to create a smooth uniform surface, only later were the cannon cast solid and the chamber created completely by boring.

Subsequently permanent foundries for the casting of cannon were established in India at number of centres, usually with European assistance and following current European practice $^{8}$. The cannon casting foundry in the Jaigarh fort at Amber, Rajasthan, is arguably the most complete such installation surviving anywhere in the world (Balasubramaniam 2008, pp.104-7). This foundry was established in the $16^{\text {th }}$ century to cast bronze cannon ${ }^{9}$ but the present arrangement with a reverbatory furnace to melt the metal, linked to the casting pit (Fig. 7), more likely dates from the $18^{\text {th }}$ or even early $19^{\text {th }}$ century.

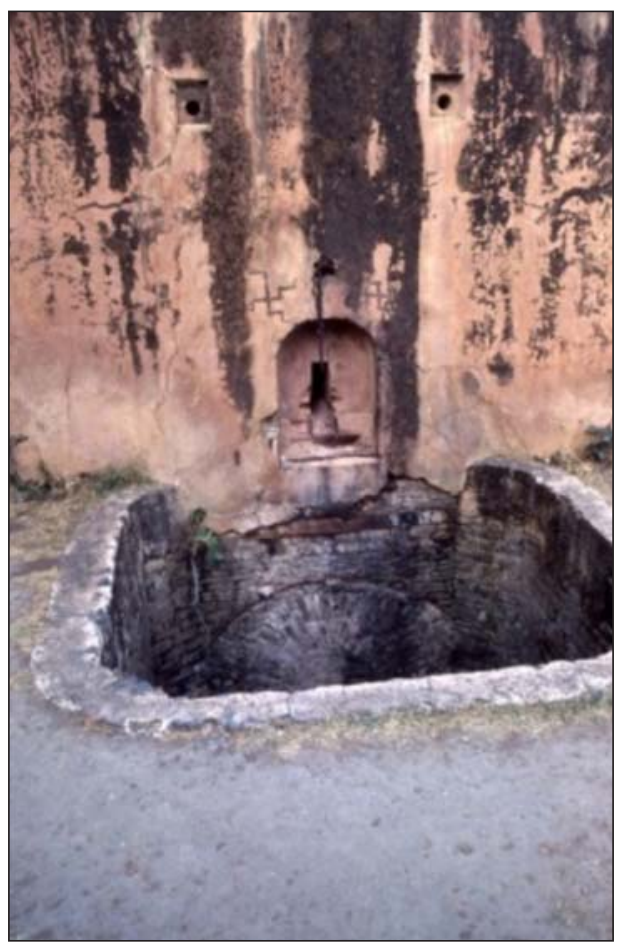

Fig.7. Reverbatory furnace discharging directly into the casting pit at the Jaigarh fort cannon casting foundry. (P. Craddock, 1984)

\section{THE ŚILPAŚÁSTRAS AND OTHER EARLY LITERARY SOURCES}

The Vedic literature frequently specifies particular metals to be used for ritual implements and vessels. Later, with the rise of the worship of idols, detailed instructions were dictated not just

\footnotetext{
8 The $18^{\text {th }}$ century European process as practiced at the brass foundry at Woolwich Arsenal, London is admirably described and illustrated in Beer ed. (1991).

9 The cannon foundries established by the Indian rulers were all for the casting of copper alloy ordnance, indigenous cast iron cannon were not produced, as Balasubramaniam (2008, p.34) remarked, 'the inability of the Indians to copy the cast iron cannon of Europe ... was a major failure.'. India has a precocious iron and steel industry, and even produced blast furnace cast iron as a feedstock for the crucible steel industry (Craddock 2007), yet there is no evidence for indigenous iron castings, all the great iron pillars, architectural beams and cannon are forgings.
} 
for their dimensions but also for their composition and production in texts such as the Śilpaśästras. In the Manasāra, believed to have been compiled originally in the Gupta period it states that 'If, in accordance with the methods here set forth in respect to the making of images is faithfully adhered to, it will lead to wealth and prosperity, but if deviated therefrom will cause poverty and distress.'(Reeves, 1962, p.29). But on a more practical note it continues that: 'However, if certain useful formulae and procedures not so described here are found in similar texts dealing with this process, there is no objection to the sthāpati (master image maker) adopting them for his own improvement.' A nice combination of ritual rigidity tempered with practical flexibility!

As with most early Indian texts there is some doubt over dates but it would seem that most of the śilpaśāstras originate in the Gupta period in North India around the $4^{\text {th }}$ to $6^{\text {th }}$ centuries $A D$, almost certainly codifying earlier practices described in the Purānas, dating back to the Mauryan period in the later first millennium BC. Reeves (1962, pp.24-35), Krishnan (1976, pp. 18 ) and Bhowmik and Jani (1998) provide accessible translations and discussion of the more important of these treatises, although they do not always agree on their dating, text and interpretation.

The Madhuchehhishthavhanam is a śilpaśāstra probably compiled in the Gupta period, although as Krishnan points out, the text currently used only dates from the $16^{\text {th }}$ century. It is found in Chapter 68, vol. 3 of the Manasāra where a technical description of a solid (Reeves) or possibly hollow (Krishnan) lost wax casting is given.

The wax is of beeswax, to which is added the tree resin dammar together with some oil. This is possibly to be applied over a core (Krishnan). Reeve's translation states that the jointures of the component parts of the body should be reinforced with copper rods or nails, and although the wax will run away there should be no objection to using these supports. If a solid casting is being described, then this could be a reference to inserting metal rods actually in the wax where it was thin to provide support during the modelling prior to casting. It is more likely though that this refers to the provision of armatures in a core as was common practice in Indian hollow lost wax casting, or just possibly it could refer to provision of metal chaplets to support the core. In either case this would suggest that it was hollow lost wax casting which was being described. This is followed by a rather strange instruction that the sthāpati must calculate what allowances should be made for the contraction or expansion of the wax model and enlarge it accordingly by adding wax to the extent necessary. In practice there would be no contraction or expansion of the wax. However, the metal casting will be slightly smaller because of the contraction of the metal as it cools. If the dimensions had to be exact then the original wax would have to be slightly larger, consequently with more wax.

Once the wax had been modelled it was covered with layers of clay, dried, fired to run out the wax, and the metal poured in. After the mould had been broken and the casting released, minor defects could be repaired but if there was major damage to the head or main body then it would have to be discarded and a fresh image made and cast anew, one of the big drawbacks of the direct process (see below).

Clearer instructions of both the solid and hollow lost wax processes are given in the Silparatna, which is also an early work. It includes instructions on the preparation of the clay bodies needed for the various ceramic components of core, mould and crucible. Clays of varying fineness and colours were to be procured from tanks and gardens as well as from anthills. They were to be tempered with fillers such as brick dust, crushed pottery, charred rice husk, cotton fabric and cow dung. The clay for crucibles was to be 
tempered with charred rice husk, crushed pottery and shredded cotton cloth (see below and Figs. 10 - 12 for the composition of Mauryan crucibles). The core was to be of hard clay (clay with brick dust and nut-husk juice) tempered with cow dung (Krishnan, 1976) over which was spread a thin layer of fine clay, three parts clay to one of crushed pot with cow dung (Reeves, 1962). Giving the core an outer layer of fine clay might seem unnecessary, but Reedy's extensive study of cores suggests they were often built up of successive layers (see below). Sheets of wax were then applied to the core and modelled. The completed wax on its core was then invested with a very soft clay described as being made up of three parts clay tempered with one part crushed pot, into which the chaplets are inserted to hold the core in place (Reeves). Alternatively the wax was moulded with a wet, very soft clay, of one part clay tempered with four parts crushed pot and cow dung. This was followed, after drying, by a soft clay of one part clay to four parts crushed pot, followed by a hard clay, containing clay, brick dust and nut juice (Krishnan, 1976). Krishnan's description continues that the outer layer of hard clay was to be bound with black iron strap and then more hard clay added until the mould was judged to be strong enough to withstand heating and the casting process. It was stated that the iron strap should pass through unimportant parts of the image. This reference to iron straps is interesting and once again it is not exactly clear what is meant. From the sequence of building up the mould it sounds like iron wire reinforcement in the mould, such as is regularly inserted into moulds now in India (see below) and elsewhere, and if so then this is the earliest reference anywhere to this practice. However, the instruction that it should pass through unimportant parts of the image suggest that an armature was meant, or possibly chaplets (as Reeves interprets them).
The completed mould was to be dried, fired to melt out the wax and bake the clay and then removed to a casting pit with the open pouring channel uppermost and the metal poured.

The Mānasollāsa, which was completed in $1131 \mathrm{AD}$, gives the most detailed account of the production of a solid casting. The figure was first modelled in wax to which wax tubes in the form of a dhātura flower were added to the back, shoulders and head or crown. The dhāturā tube would have the form of a stem terminating in a hemispherical bowl, necessary for the pouring channels. The wax was then weighed and from this the amount of metal required could be easily calculated $^{10}$. The moulding clay was to be tempered with charred husk, shredded cotton (cloth?) and a little salt. The first layer should be so thin as to appear transparent and left to dry for two days in the shade (to avoid cracking). A second layer was then added and again left to dry slowly before the application of a third thicker layer, leaving the tops of the dhāturā flowers exposed, and the whole carefully dried.

The crucible was to be made by wrapping clay around the metal to be melted, forming a closed shape described as being like a coconut and left to dry. This is an extraordinary way to make a crucible (discussed further below). The mould was then fired to drain out the wax and the 'crucible' was strongly heated and when the metal was judged to be molten a hole was punched in the top and it was lifted out with tongs and the metal was carefully poured into the open mould channels, in which a lighted wick had been placed. After casting the tubes were removed.

The reference to forming the crucible around the metal is most strange, unless a combined mould-cum-crucible was meant, where the crucible really is formed around the metal to

\footnotetext{
${ }^{10}$ The figures given are X 10 for a copper alloy, X 12 for silver and X 16 for gold. The figures are broadly correct except that for gold which would be X 24, suggesting that on the rare occasions that gold was used it was debased approximately 50 : 50 with copper.
} 
be melted sat in the bowl on the top of the mould, and is still practised by the traditional Indian tribal casters etc. (see below, and Figs. 20-22). However the rest of the detailed description states quite clearly that the mould and crucible were separate and the metal was poured from the crucible.

\section{Refractory Evidence: Crucibles AND CORES}

The archaeological evidence for casting operations in South Asia is singularly frustrating. Many of the Harappan urban sites have produced evidence of metallurgical activity in the form of furnaces, slags and vitrified ceramics. These were originally interpreted as smelting sites but are now regarded as more likely to be connected with casting and other metallurgical operations (Kenoyer and Miller, 1999; Agrawal, 2000, pp.3747). However no evidence was found of the mould material, but mainly of crucible fragments (Agrawal, 2000, pp.39-40). Crucibles have been recorded from a number of excavations at other sites in South Asia (Bhardwaj and Sharma, 1997, Section 1: crucibles, pp.3-14; Sharma and Bharadwaj, 1986). There is a similar situation at the major Mauryan silver- smelting site at Dariba in Rajasthan (Craddock et al., 2013). Surveys located a recent well that had cut through a deep deposit of metallurgical debris with a great deal of vitrified and slagged refractories including many crucibles (Figs. 8 \& 9), some with lids. Analysis revealed that in almost every case the vitrified surface that had been in contact with the molten metal contained copper and tin. In the Mauryan period Dariba was worked mainly for lead and silver, there was some copper, but the deposit does not contain tin. Thus the operations carried on at this particular site are unlikely to be primary smelting, but rather for metalworking where bronze was being melted presumably as part
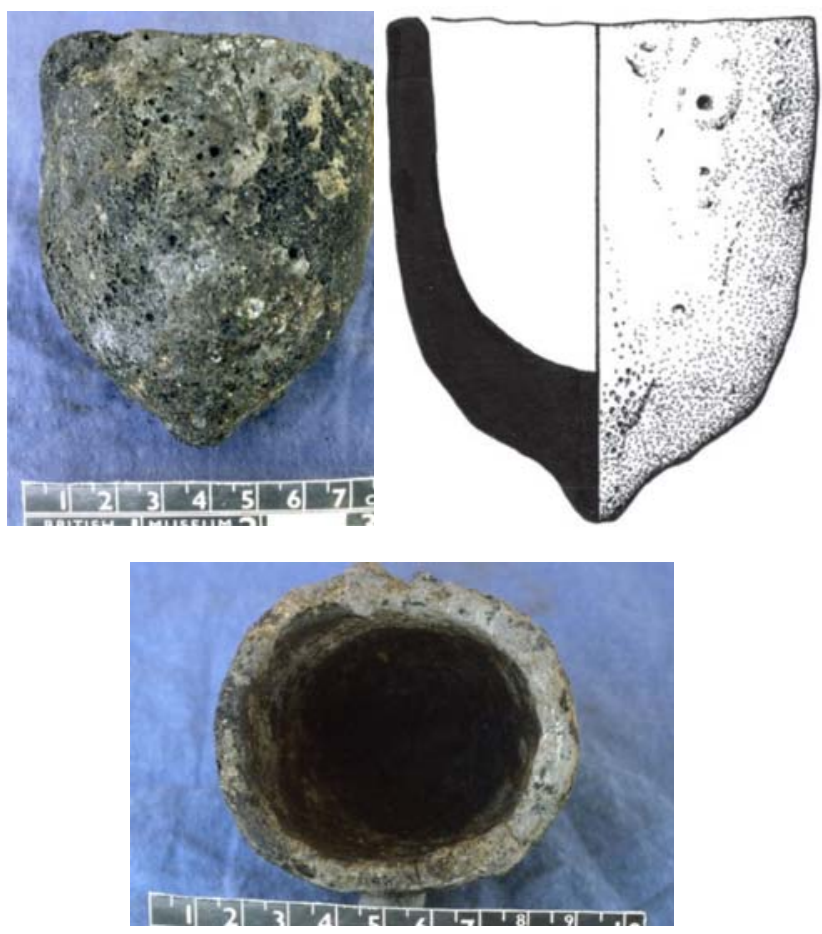

Fig. 8a, b \& c Large crucible for casting bronze from the foundry excavated at the silver mine at Dariba, Rajasthan, Mauryan, $3^{\text {rd }}$ century BC. Note the nipple on the bottom to raise the base in the fire. Note $(8 \mathrm{c})$ that it is oval to assist gripping with tongs. (8a \& c P. Craddock; 8b B.R. Craddock / British Museum.)

of casting operations. As at the earlier Harappan sites no evidence of the moulds was found.

Many of the crucibles were quite large and deep. The complete example shown in Fig. 8 has a capacity of about $150 \mathrm{~cm}^{3}$, and thus could have held about $1.2 \mathrm{~kg}$ of copper alloy ${ }^{11}$. The vitrification of the clay was most pronounced on the outer convex faces, showing that the crucibles had stood in burning charcoal. Many have pronounced nipples on their bases which would have raised the base slightly to ensure that the burning charcoal was beneath as well. This is quite a common feature on early crucibles in India and can be paralleled by crucibles from Chandraketugarh in the North Parganas District

\footnotetext{
${ }^{11}$ This was about the maximum capacity of early crucibles. The largest modern graphite crucibles used at Swamimalli, Tamil Nadu have a capacity of about $60 \mathrm{~kg}$ copper alloy (Levy et al. 2008, pp.72-3); those of the smiths at Chamba in Himachal Pradesh have a maximum capacity of $50 \mathrm{~kg}$ (Reedy 1987).
} 

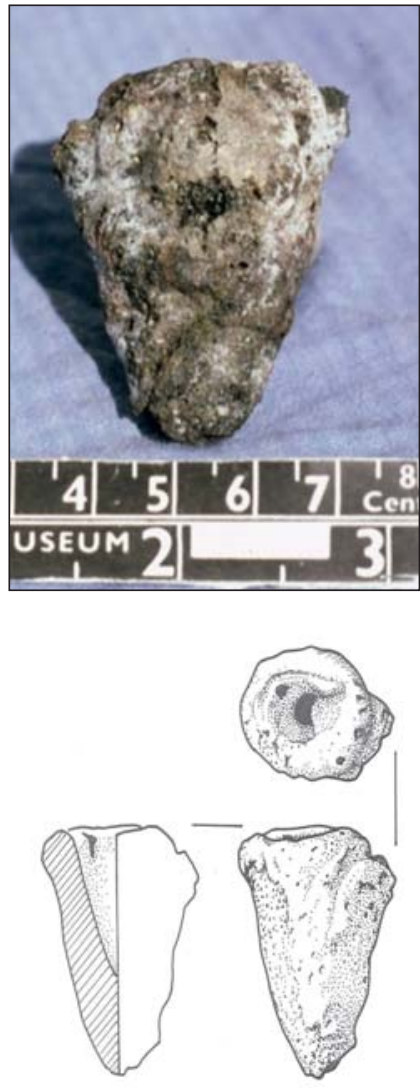

Fig. 9a \& b Tiny crucible with a capacity of only $20 \mathrm{~cm}^{3}$, from Dariba. (9a P. Craddock; 9b B.R. Craddock / British Museum)

of West Bengal, dated to between the $2^{\text {nd }}$ centuries BC- $2^{\text {nd }}$ centuries AD (illustrated in Chattopadhyay 2004, p.143, plate 1A).

Scientific examination showed that typically the clay paste of the crucibles (Fig. 10) contains silt/fine sand, which is angular and mainly of quartz and feldspar. In addition, there is sparse coarser sand up to c. $1 \mathrm{~mm}$, which includes some feldspar and rare grains of metamorphic minerals such as staurolite and garnet. In most examples the matrix is vitrified and bloated, but one example, a crucible lid, includes a non-vitrified region, which was micaceous. All the crucible sherds contain abundant vegetal temper, identified as short 'chopped' lengths of rice and sorghum stems, rice and sorghum husk fragments and short lengths of wheat and barley straw.

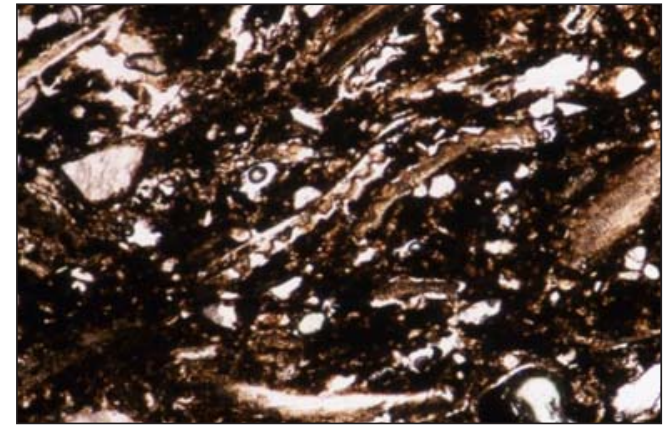

Fig. 10 Photomicrograph of thin section of crucible, similar to Fig. 8, showing the vegetal fibre-rich fabric. Plane polars, width of field c. $2 \mathrm{~mm}$. (A. Middleton / British Museum)

It is evident that the crucibles were made in a distinctive fabric in which the clay used for ordinary domestic pottery was tempered by the addition of coarse quartz and very large proportions of vegetal temper. The addition of vegetal temper to modify the behaviour of pottery clays during forming, firing and use is well known in India, as specified in some of the Silpaśāstra accounts (see above). Gajurel and Vaidya (1984, p.44), describing current Nepalese practice, state that crucibles should be made of a refractory containing one pathi (four kg) of beaten rice husk, one dharn̄i (2.4 kg) of gicha (rough) clay to which were added four handfuls of sand and left in the dark for proper ageing.

Polished sections from two of the Dariba crucibles were examined and analysed by scanning electron microscopy to establish the conditions under which they were used. They varied in texture from a continuously vitrified and bloated texture (Fig. 11), to a partially vitrified texture with little bloating (Fig. 12) in regions exposed to less severe conditions. It is estimated from the degree of vitrification that the crucibles were heated to a temperature in the region of $1150^{\circ} \mathrm{C}$. The hotter surfaces, which exhibit the most developed bloating, correspond to the convex, exterior surfaces.

In common with most early ceramics from South Asia and elsewhere the crucibles were made 


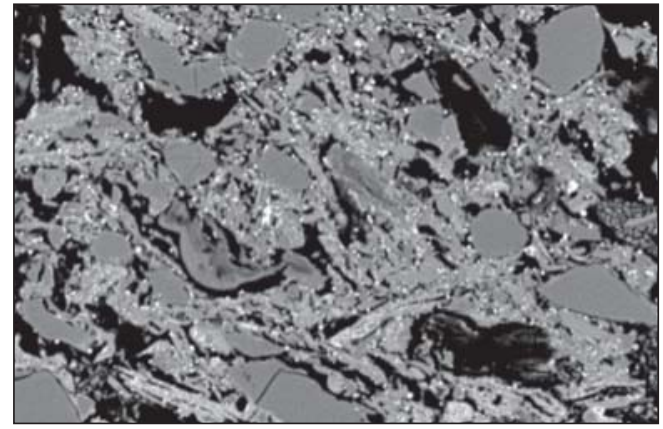

Fig. 11. SEM photomicrograph of polished section of crucible fragment showing vitrified texture and fine subspherical particles of iron as white dots. BEI, scale bar $=20$ $\mu \mathrm{m}$. (A. Middleton / British Museum)

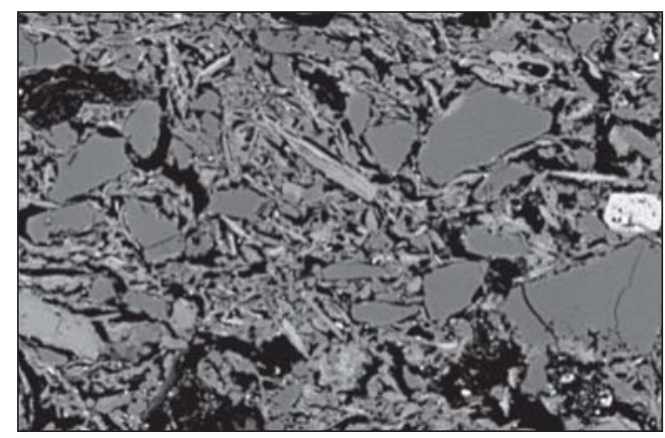

Fig. 12. SEM photomicrograph of polished section of crucible fragment, showing less vitrified portion of the ceramic. BEI, scale bar $=20 \mu \mathrm{m}$. (A. Middleton / British Museum)

from clays that are not particularly refractory (Freestone and Tite, 1986). Analysis showed that the clays used are ferruginous (c. 7\% FeO) and that the total alkali content is rather variable (c. 4$8 \%$ ), probably reflecting the inhomogeneous distribution of mica. The dark grey-black colour of the crucible fabrics suggests that they were situated in parts of the furnace where the air supply was restricted. This inference is supported by the identification of minute spherules of iron within the fabric of the most heavily vitrified parts of the crucibles (Fig. 11). The very high levels of vegetal temper included in the clays will also have contributed to this reducing atmosphere, and to a general enhancement of their refractory performance, as also observed in the crucibles used in the production of 'wootz' steel in India
(Freestone and Tite, 1986). This reduction of the iron oxides in the fabric had the effect of reducing by more than half the amount of iron available to act as a flux in the clay. In addition the use of organic temper would also have been important in helping to maintain a reducing atmosphere within the bowl of the crucible and may also have conferred other improvements, such as heat transfer, shrinkage and thermal shock resistance (Skibo et al., 1989).

\subsection{The cores}

The other refractory associated with the casting operation still to be available for scientific study are the cores surviving in some hollow castings, in which the studies of Chandra Reedy have been outstanding (Reedy, 1991; 1992; 1997 and 2003).

Some reference to hollow lost wax casting seems to occur in the early texts and technical examination of the early metalwork confirms that hollow casting was used. The choice between hollow and solid casting depended on a number of quite disparate factors, ritual as well as practical. Thus in south India where the form of the image is strictly controlled, truly divine figures were and continue to be solid castings, although the nonhereditary casters do produce hollow castings; conversely in the Himalayas it became a practice to insert religious items such as texts into the body of the hollow figure. The figures produced by the tribals of central India could be either solid or hollow, to some degree a solid casting being regarded as a more de-luxe version of a hollow casting.

There are also practical considerations, especially with large castings. A solid casting of a life-size figure could easily contain several hundred kilos of metal. Quite apart from the cost and weight factors, there would be major problems in casting such a figure. The largest early crucible would have contained about a kg of metal and thus somehow hundreds of crucibles of molten metal 
would have had to prepared and poured in a fast continuous sequence (unless special cupola melting furnaces were employed to run the metal directly into the mould, but there is no evidence for this in India before the first accounts of the casting of cannon in the $16^{\text {th }}$ century (see above and footnote 7). Even if the metal was successfully poured further problems would be encountered as the metal set. Inevitably the first metal to set would be against the mould walls but the metal in the interior would still be cooling and contracting, producing very considerable strain, causing severe distortion or even stress cracking in the casting.

The core material has to have very specific properties, very different from those of the mould (Craddock, 2014). It must retain its shape during the casting process whilst the molten metal flows around it, supporting the solidifying metal. During the actual pouring of the metal, even into a red hot mould there is likely to be some additional gas generation and expansion that can only be dealt with by absorption into the core (absorption into the mould would, of course, ruin the casting). Thus an open structure is necessary and was usually achieved in the past with large quantities of dung and vegetal material, often with quite macroscopic straws, now visible as voids. Sometimes a central spine of light wood or even twisted grass ${ }^{12}$ was inserted to act as flue to remove the gases generated. The core also has to have the strength and rigidity to withstand local pressures and not to shrink or crack whilst the metal is molten as well as to withstand thermal shock for which a sandy clay is desirable. However, after the initial solidification, the metal will continue to shrink, which the core must accommodate in order to avoid serious stress and potential cracking in the casting. These two requirements are usually met by the addition of large quantities of crushed rocky filler, typically silica in one form or another, which ensure surface rigidity during the few moments of solidification, but the voids created by the burnt out vegetal material enable the core to 'give' a little whilst the metal contracts.

\section{The South Indian BRonzes}

The bronzes images of southern Indian have attracted a large literature, and several studies of the casting processes as carried on at traditional centres such as Swamimalli have been made including Reeves (1962, pp.101-15); Krishnan (1976, pp.9-21); Kuppuram (1989, pp.457-68); Craddock and Hook (2007); Levy et al. (2008).

The usual alloy in the past was of bronze often with some lead for the images from southern India (Werner, 1972, pp.186-9, tafel 5.1; Craddock and Hook, 2007), Sri Lanka (Reedy and Harlacher, 2007; Craddock and Hook, 2007) ${ }^{13}$. It seems that from the post-medieval period zinc began to appear in the alloy along with tin and lead. Given the widespread use of scrap metal in the alloys the incorporation of zinc from scrap brass was inevitable. Reeves (1962, p.108) describes the mid $20^{\text {th }}$ century alloy used at Swamimalli as containing $75 \%$ of copper, $15 \%$ of brass, $5 \%$ of tin and $5 \%$ of lead. ${ }^{14}$

It was often decreed in texts, such as the $12^{\text {th }}$ century Sri Lankan Sāripūtra text, that the images of deities intended for ritual purposes had to be solid castings, such as the famous $8^{\text {th }}$ century Bodhisattva Tārā, from Trincomalee, now in the

\footnotetext{
${ }^{12}$ The smiths at Chamba in Himachal Pradesh wrapped grass around the iron armature to create a flue in the core (Reedy 1987).

${ }^{13}$ Reeves (1962, p.108) makes the valid point that the term 'bronze' is used indiscriminately to describe any copper alloy, whereas strictly speaking the term should be used only for alloys of copper and tin. This is quite true and laudable. Unfortunately she then went on to state that true bronze was only rarely used in India, whereas subsequent analytical programmes have shown that bronze was used in the south.

${ }^{14}$ Volatile zinc is quite difficult to successfully alloy with copper; it is much better to use a commercially available common brass containing approximately two parts copper to one of zinc. $15 \%$ of this added to the alloy equates to $5 \%$ zinc overall, giving an alloy containing $5 \%$ each of tin, zinc and lead, which is the composition of the modern western statuary 'bronze'.
} 
British Museum, Reg. 1830-06-12, 4. The hereditary casters of Swamimalli still mainly produce only solid castings (Levy et al., 2008). However, hollow castings were certainly not unknown in the past (Venkatraman et al., 1993), especially for larger figures, as exemplified by the Sultanganj Buddha (see above, and Fig. 2), and not just for reasons of economy as outlined above. The production of solid castings has been described by both Reeves and more recently by Levy et al, and in essentials is not dissimilar to the process for producing solid castings in the Himalayas (see below), and it is the production of hollow castings by the so-called entrepreneurial foundries that will be described here as observed by the author in 1986 (Craddock and Hook, 2007).

A core is prepared from sandy clay modelled around an iron armature, if considered necessary. The core usually comprises the torso, upper limbs and sometimes the head (Fig. 13). The lower arms together with the hands and the lower legs together with the feet, are usually solid.

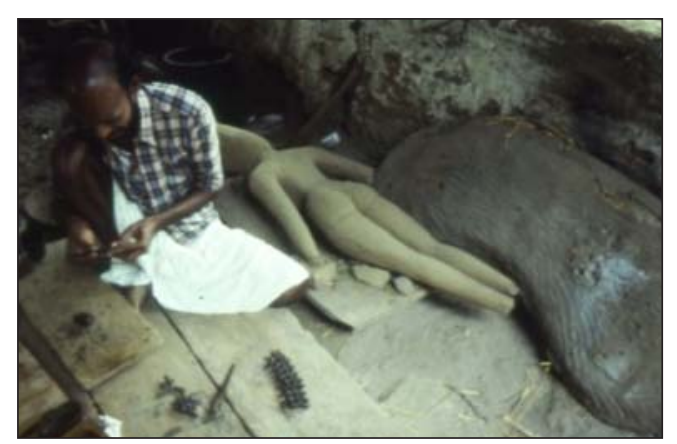

Fig. 13. Clay core for life size figure (left) and finished mould (right). Swamimalli. (P. Craddock, 1986)

The dried and fired core is covered with sheets of wax of the required thickness ${ }^{15}$ and the fine modelling of the figure is performed (Fig. 14). Alternatively, the limbs are moulded separately and then attached to the main torso with metal dowels in the core (Fig. 15). An important

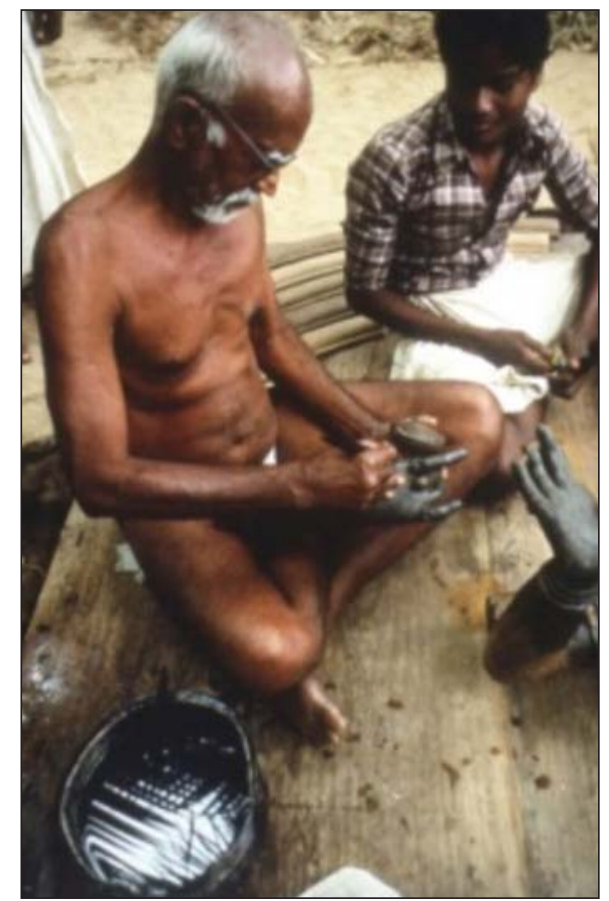

Fig. 14. Fine modelling of the 'soft' outer layer of wax (see endnote 15) by the sthāpati attended by his apprentice.

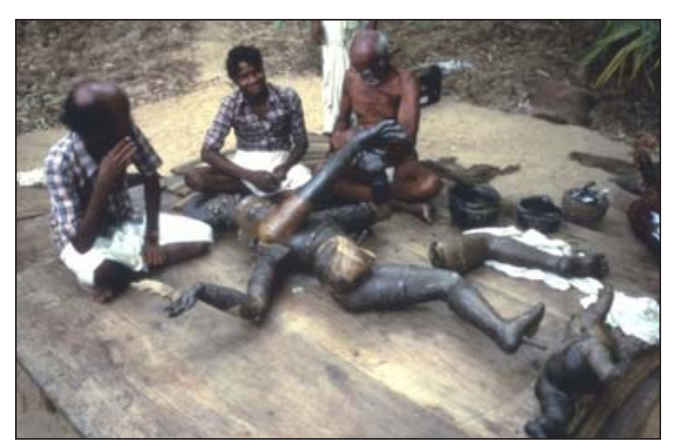

Fig. 15. Limbs formed separately to be fixed to the main torso model with dowels.

distinction of the south Indian tradition is that the figure, no matter how complex, is cast as one, with the exception of the base. This is perhaps most remarkable in the Siva Natarāja figures where the thin encircling prabhāvalī ring of fire is part of the main casting. For this a quite complex series of pouring and feeder channels are required (Fig. 16). The wax is then invested with clay built up in

\footnotetext{
${ }^{15}$ The wax was traditionally of beeswax with additions of dammar or other resins, softened with vegetable oil. Nowadays for solid castings paraffin wax is used mixed 50 : 50 with resin for the basic 'hard' wax model over which a 'soft' wax layer of beeswax is laid (Levy et al. 2008, pp.56-7). This layer is finely modelled (Fig. 14).
} 


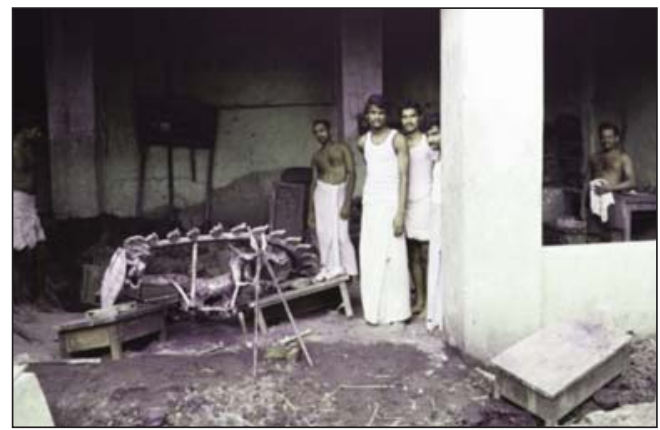

Fig. 16. Large Śiva Natarāja casting just removed from the casting pit. Note the whole assemblage has been cast in one, and the complex arrangement of feeders and risers now lying underneath as the casting has been turned over.

layers. The first layer is of river silt and clay obtained from the River Cauvery, mixed with strained cow dung, and applied as a cream. When this has dried another layer is applied, this time a little stiffer and thicker. Then a mesh of iron wire is fitted around the mould and the outer layers of rough field clay built up around the mould.

After drying for several days the mould is placed in the casting pit (Fig. 17). The major castings were, and continue to be cast lying face down, approximately horizontally but with the head of the statue slightly lower. The study by Johnson (1972) of an early failed solid casting is very instructive (Fig. 18). This showed that the figure had been cast lying face down with the metal channelled straight to lowest part of the casting, such that the smith could judge that the mould had been successfully filled when metal appeared in the riser channels at the other end. In this instance the metal set before it had completely filled the upper part of the mould and so even before breaking the mould the smiths would have known there were serious problems which in this instance they were unable to rectify.

The mould positioned in the pit is gently fired with cow dung cakes to melt and burn out the wax. Then whilst still hot the mould is firmly

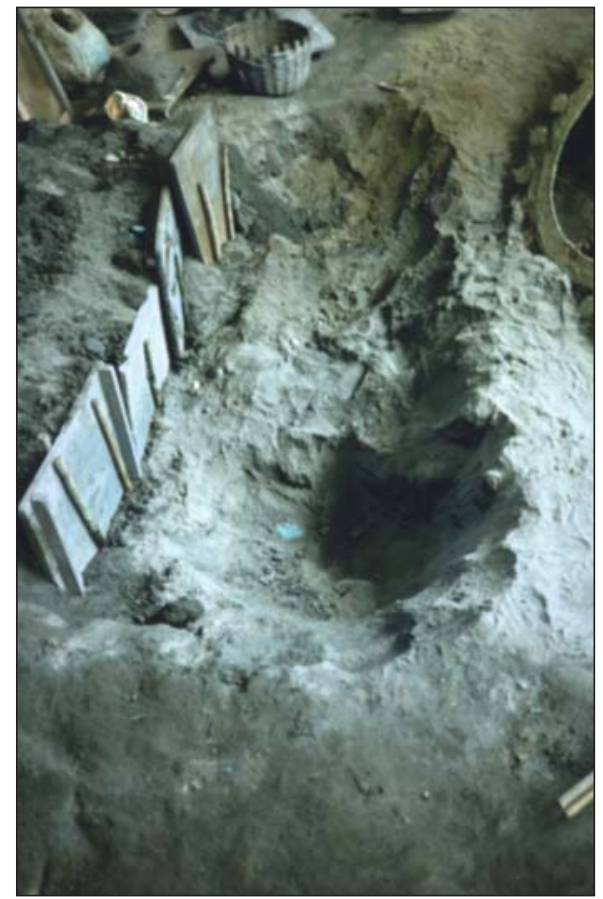

Fig. 17. The casting pit in which the Siva Natarāja (Fig. 16) was cast, lying face down at a slight angle.

packed with sand and the metal poured from crucibles that can now hold up $60 \mathrm{~kg}$ of metal but which in antiquity are unlikely to have held more than about a kg. This means that for some of the larger Chola statues multiple crucible pourings would have been necessary in quick succession from several furnaces operating together, in what must have been a highly organised and practised routine ${ }^{16}$.

Even so mishaps were and are inevitable, and as the Mānasāra instructs, small faults such as those on the arm of the Siva Natarāja (Fig.19) could be repaired, usually by cutting out the damaged area and mechanically hammering in a fresh plate of metal. Major faults such as those shown on the statue (Fig. 18) were beyond remedy and the casting abandoned. It is sometimes stated that ideally the casting should appear from the mould requiring no further treatment. This is very mistaken, as can be seen in Fig. 19, where not

\footnotetext{
${ }^{16}$ Despite the fact that the Śilpaśāstra only mention crucible casting, one wonders whether running the metal in directly from several furnaces was practised, as it was a few centuries later for casting cannon (see endnote 7).
} 


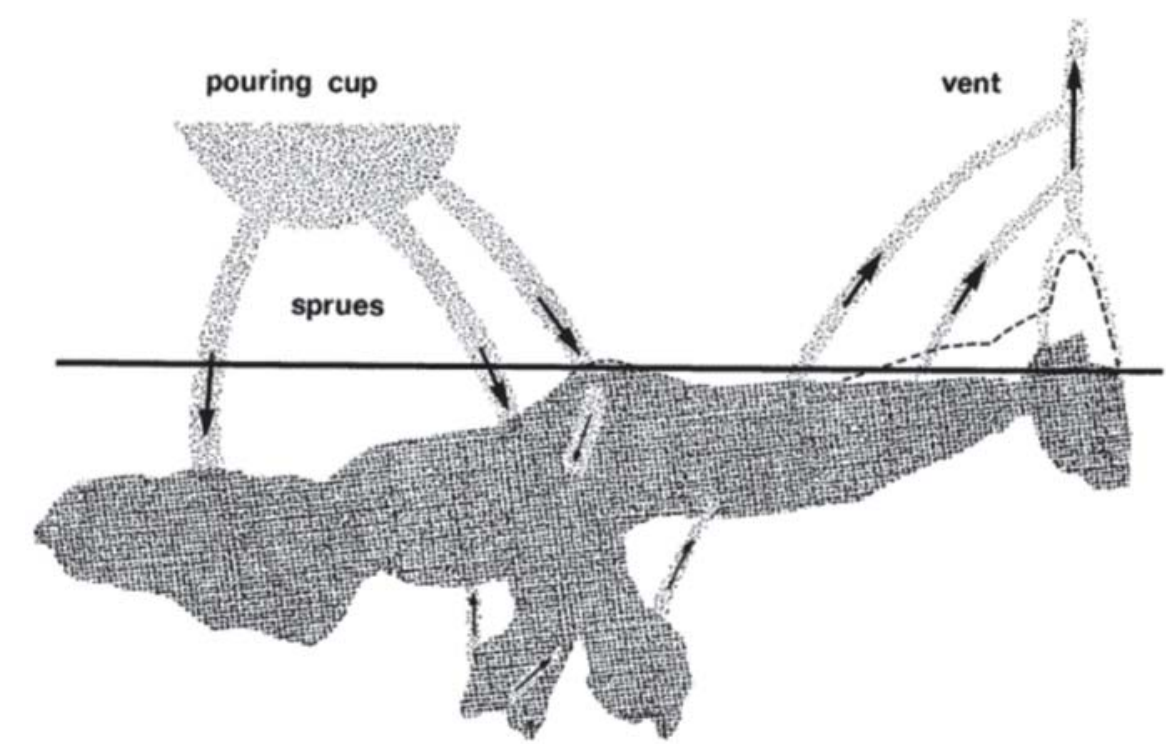

Fig. 18. Diagram showing how a failed casting of $B \bar{a} l \bar{a}$-Krishna must have been cast. It is probable that each of the sprue and vent channels were in fact individual pouring channels, rather than the one large pouring cup as depicted here (from Johnson, 1972)

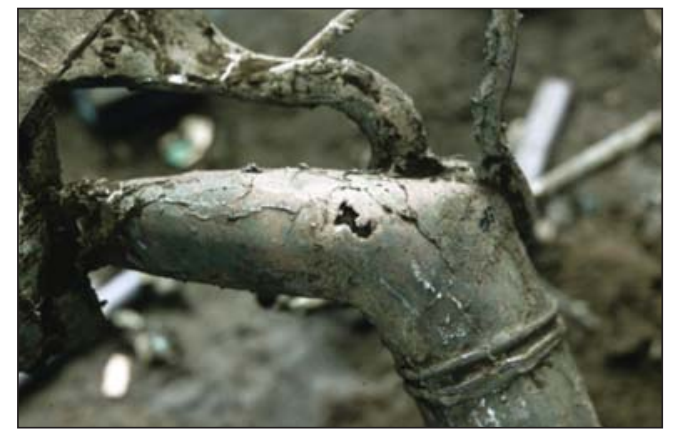

Fig. 19. Close up of an arm of the Siva Natarāja (Fig. 16) showing an area where the metal failed to run as well as the network of metal on the surface where the metal ran into cracks in the mould clay.

only were there minor areas where the metal had failed to flow, but there was a network of metal flashes on the surface where the metal had entered minor cracks in the mould. Despite all the precautions with careful drying of the mould some cracking is inevitable and the flashes have to be filed flat. Then will begin the long process of scraping, followed by burnishing, performed to consolidate the surface, together with chasing to sharpen up details (Levy et al., 2008, pp.78-82). These operations are then followed by a succession of careful polishing and washing operations (with tamarind water).

\section{The Tribal Tradition}

As noted above the tribal metal smith communities have been carefully recorded in the Indian census of the 1960s (Nambiar, 1964, etc.) and brought to a wider audience by Reeves (1962). They now operate mainly in remote areas, but are very likely to have once been much more prevalent. In common with much of tribal culture, they have received relatively little attention from the art-historians and thus their origins and development are little known ${ }^{17}$. Few 'tribal' castings have been identified from archaeological excavations, but they could have a very long history ${ }^{18}$.

\footnotetext{
17 This is now fast changing with institutions such as the excellent ethnographic Museum of Man at Bhopal, covering all aspects of tribal life.

${ }^{18}$ The four well-known bronze figures of an elephant, buffalo, rhinoceros and a chariot, found at Daimabad, Maharastra (Sali 1986), could well be in the tribal tradition. They are solid bronze castings with a total weight of over $60 \mathrm{~kg}$. Although unstratified, they are variously claimed as Harappan or Chalcolithic, but a date in the early historic period seems as likely.
} 
The tribal technology is quite distinctive not only from one group to another, even when living in close proximity to each other, but in many aspects significantly different from the more sophisticated and better known casting traditions of the Himalayas and of South India. ${ }^{19}$

Three aspects of the tribal technology in particular are very distinctive and probably indigenous developments:

1. Tree resins used as a substitute for wax.

2. The model is often built up by winding wires or thin strips of resin or wax around the core instead of using sheets of wax.

3. The combined mould-cum-crucible method of casting (Figs. 20-22) ${ }^{20}$.

Inevitably technique and style are intertwined, although whether the technology dictated the distinctive shapes and styles or

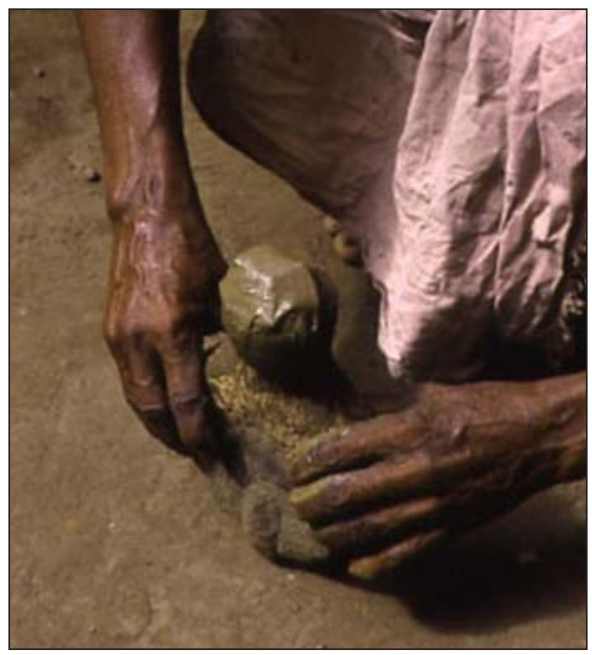

Fig. 20. Building the crucible around the metal to be cast on a mould-cum-crucible arrangement for casting mirror discs at the workshop of M.S. Janardhanan Achary at Aranmula in the Alleppy District of Kerala. (P. Craddock, 1994)

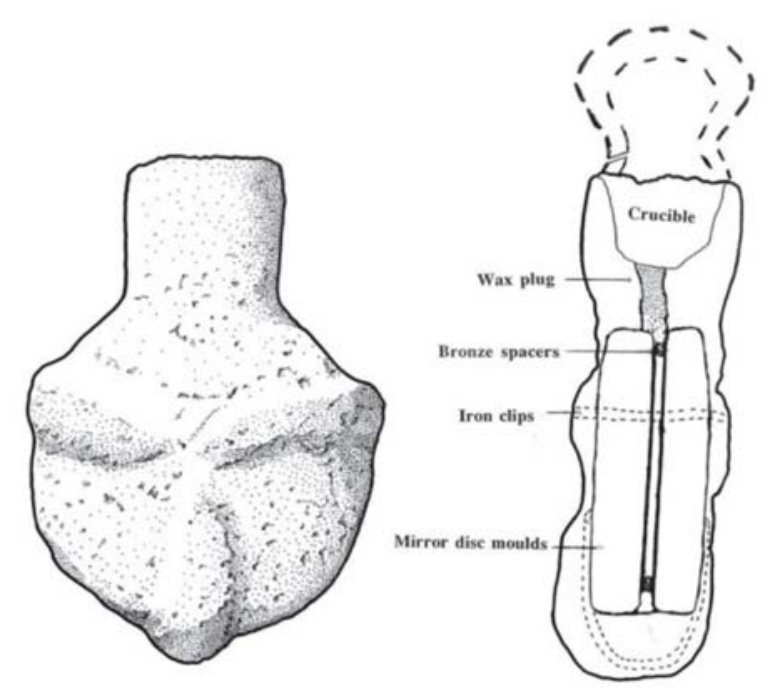

Fig. 21. Cross section of a mould for casting mirror discs (See also Figs. 20 \& 22). The crucible and pouring channel arrangements are identical to those used by some tribals to cast images. Note the gap in the crucible made by incorporating a straw through the clay to create the essential air space. (adapted from Srinivasan and Glover, 1995)

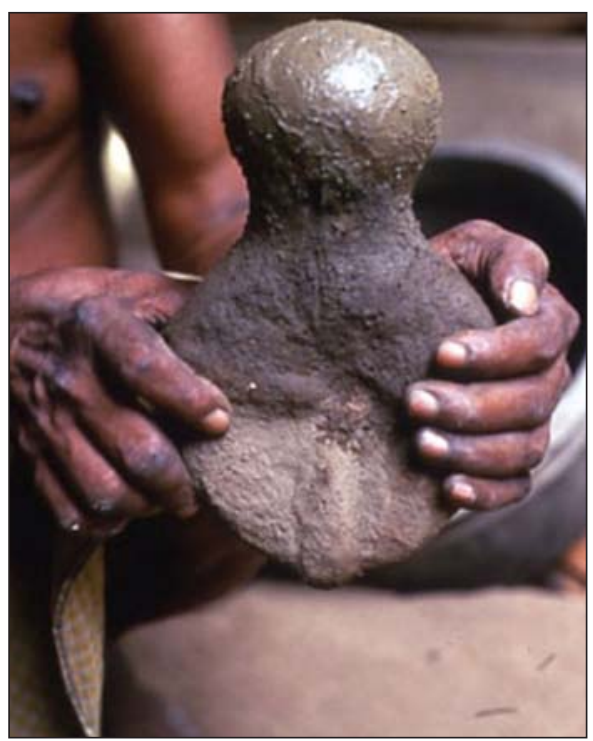

Fig. 22. Completed crucible on the mould. After drying the assemblage will be inverted and placed in the hearth with the crucible beneath in the hottest part of the fire. (P. Craddock, 1994)

\footnotetext{
${ }^{19}$ Reeves (1962, 79-84) pointed out that, for example, the Malar tribals live in land that was once Gupta territory, yet there is neither stylistic nor technological affinity between their metalwork. Reeves (p.84) believed that the present tribal smiths and their products represent an indigenous, possibly pre-Vedic, tradition that continued alongside the more advanced Buddhist Hindu inspired Gupta tradition, and in North India outlived it.

${ }^{20}$ The mould-cum crucible method is illustrated here by the arrangements used by the traditional mirror makers of Kerala to caste the bronze mirror discs (Srinivasan and Glover, 1995; Craddock and Hook, 2007).
} 
whether it was the other way around, with the required appearance dictating the technology adopted is uncertain. Reeves (1962, pp.11-16, Plates 4 \& 5), argued that brass figurines built up of wire-work are translating the pre-existing tradition of building figurines from coiled grass into metal, this taking place probably back in remote antiquity.

The castings are almost universally of brass, incorporating mainly scrap metal. The modelling material is prepared from tree resins, notably dhuna, from the sal tree (Shorea robusta) which is boiled with mustard oil. This when warm is almost as malleable as beeswax, and on cooling is considerably harder and stronger. The warmed dhuna is pulled out into wires and tapes 30 to 40 $\mathrm{cm}$ in length and $2 \mathrm{~mm}$ thickness, the tapes vary in width but are usually less than one cm wide. With this the Kainkuya Mal caste of itinerant smiths, at Bankura, West Bengal, for example, produce Hindu deities and rice-measuring bowls.

Most of the figures are hollow castings, the core being of sandy clay tempered with vegetal matter. After the core has been shaped and dried the model is built up by winding the softened dhuna strip around it. As Reeves pointed out, in fact for these figures the only true modelling as such is in the core. The use of strips allows patterning, in particular on some figures the dhuna strips or wires criss-cross over the core leaving diamond-patterns of exposed core (Reeves, 1962, p.41, Plate 14). When the completed model is invested the mould clay joins up with the exposed core and will hold it in place during the firing and casting operations. After the mould has been removed the core is left in place, partly to support the very thin casting (typically only two mm) but also to provide a contrast in colour and texture with the brass. Another technique is to construct an openwork figure completely of thin rods of resin to create a filigree effect.

As already noted, the mould-cum-crucible technique is used, and the provision of the pouring channel(s) is interesting, and again apparently unique to the tribal casters. Bamboo splits are inserted through the inner clay mould into the dhuna inside. More clay is now modelled around the inner mould and the splits to hold them in place and left to dry. Meanwhile the pouring channels formed of two rods of dhuna are inserted into the base of a small clay cup which will form the lower portion of the crucible and more moulding clay wrapped around them. When the clay around the bamboo splits has dried they are pulled out leaving two channels into which the dhuna rods are inserted. Now the coarse outer mould clay, well tempered with rice husk, is built up around the inner mould and pouring channels up to the level of the clay cup. Into this cup the broken up pieces of metal are placed and the crucible completed with more clay, with just a thin sliver of straw running from the inside of the mould through the clay layers of the mould creating a small air gap. This is essential as the mould-cum-crucible is otherwise a completely sealed unit and would explode on heating. After drying the whole assemblage is baked in a horizontal position with the crucible innermost to receive the highest temperatures to ensure that the metal is fully molten. When it is judged that this has taken place the mould is removed, and after a short space of time, raised with the crucible uppermost allowing the metal to flow and consume the remains of the dhuna. Other tribal casters such as the Malyar at Ranchi, Bihar, fire the assemblage inverted with the crucible beneath and when the metal is molten the red-hot assemblage is carefully righted.

Other tribal casters such as the Thetari Rana of Orissa and the Kaser of Jagdalur, Bastar, Madhya Pradesh, produce the dhuna wires or strips by extruding the warm resin through a wooden board pierced with holes, rather in the manner of noodles. It might be thought that this extensive use of wires and strips was in some way connected with the use of resin instead of wax, but this is not so, the Kaser, for example, use beeswax. 


\section{North Indian and Himalayan images}

The metalsmiths of the Himalayas have developed a wide range of techniques for producing items such as vessels and figures. These could be made from sheet metal (Dagyab, 1977, pp.47-9; Gajurel and Vaidya, 1984, pp.32-7) or cast by 'mud casting' (a variant of sand casting, see above) or by a variety of lost wax techniques, including both direct and indirect techniques (Fig. 23). All are indigenous and apparently of considerable antiquity.

From the end of the first millennium BC through to the present day statuettes of the various deities etc. have been produced in huge numbers. Some were excavated at Taxila, and found to be solid lost wax castings of leaded bronze (Prakash and Rawat, 1965). In the subsequent Gandharan period the majority of the figures were also solid cast but there was a marked change of composition with the introduction of brass (Reedy, 1992). Some brasses had been found at Taxila, but now, for the first time in India, zinc was often a component of the alloy. Overall the alloys could be bronze, brass or a mixed alloy, and lead was a regular addition. Very many statuettes from across the whole North India- Himalayan region have been analysed and show that overall through the centuries the prevalence of brass increased as well as the zinc content ${ }^{21}$. The early brasses are likely to have been made by the cementation process, in which the copper was reacted directly with calcined zinc mineral, but by the Medieval period at the latest zinc metal was being used for coinage in the

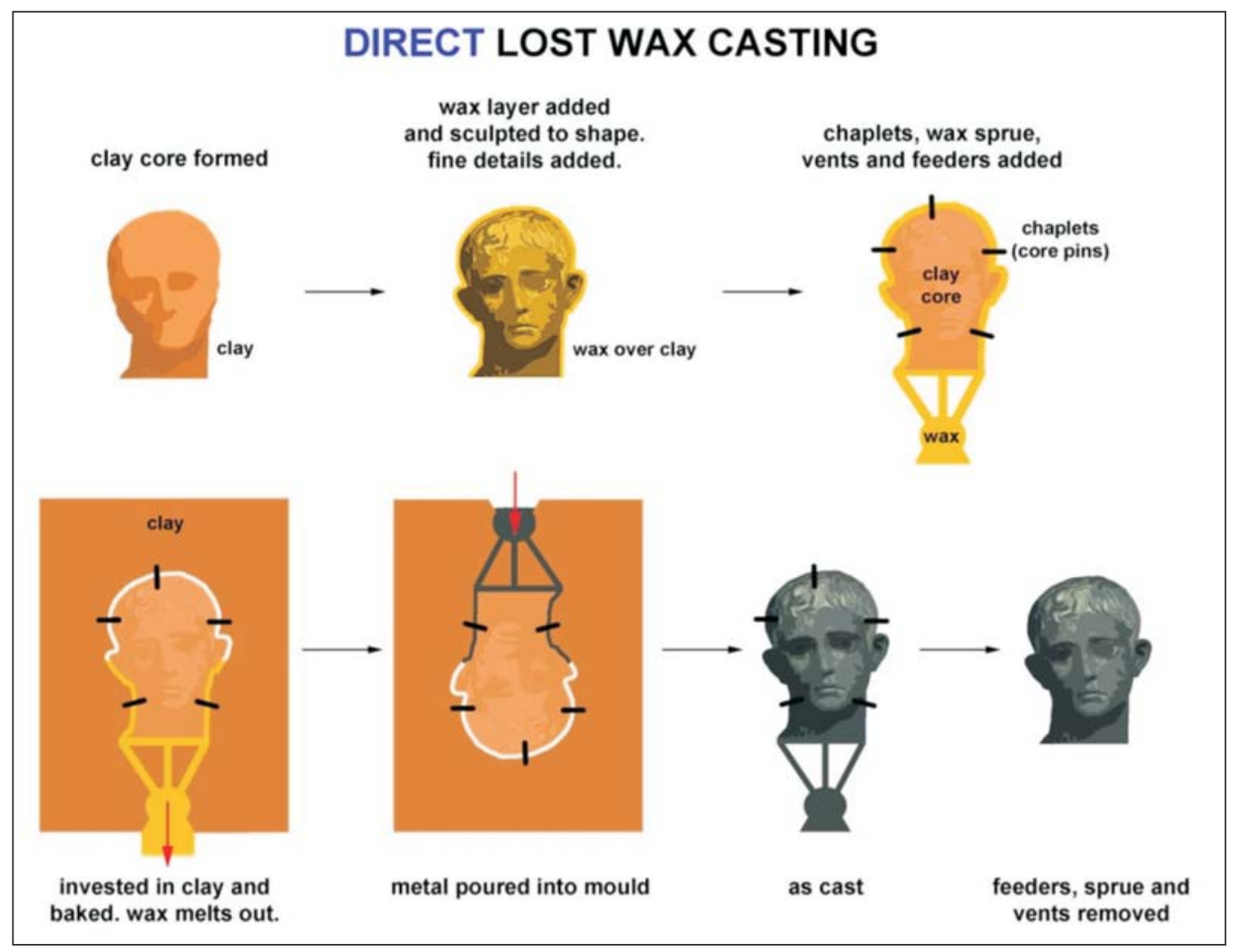

Fig. 23a. Direct hollow lost wax casting. (T. Simpson and S. La Niece)

\footnotetext{
${ }^{21}$ The analytical papers include: For Tibet and Nepal- Craddock (1981); Dubrovin (1990; 1992). For North and North West IndiaWerner (1972, pp.184-6, tafel 4.1 \& p.190, tafel 6.1); Swarnakamal (1980); Lal (1956); Riederer (1979; 1984; 1985; 1991). For the Himalayas generally- Nieuwenhuysen and Adams (1984); Reedy (1992; 1997); Riederer (1989);. North Pakistan- Reedy (1997). Kashmir- Pal (1976). Many of these analyses are tabulated in Prakash and Rawat (1965) and Chakrabarti and Lahiri (1996).
} 


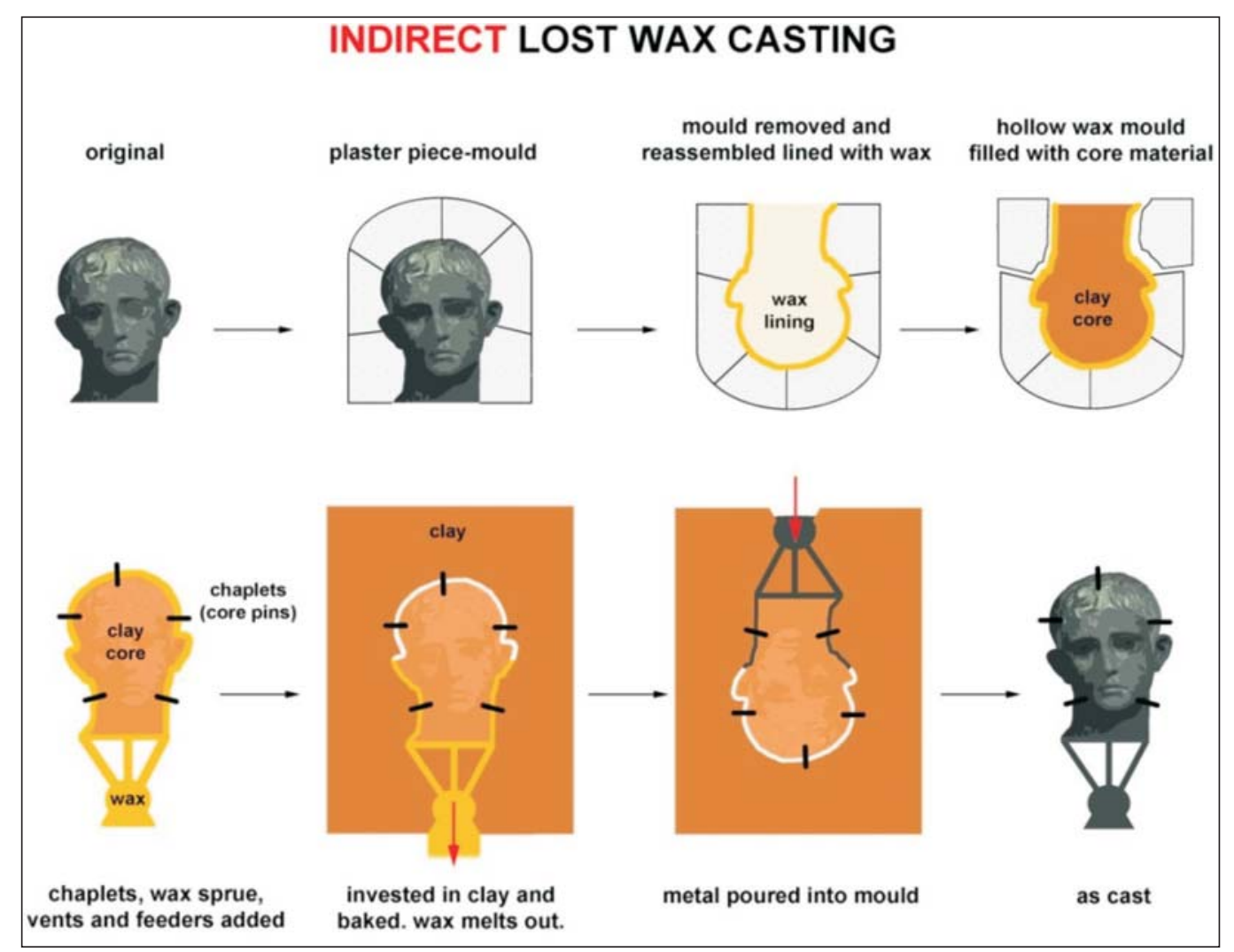

Fig. 23b. Indirect lost wax casting. (T. Simpson and S. La Niece)

Himachal Pradesh-Punjab region (Craddock et al. forthcoming) and it is likely that from then on brass was made by speltering, that is mixing the two metals, copper and zinc. The main exception to this was where the images were to be mercurygilt, which were usually cast in copper ${ }^{22}$.

For solid castings the figure are modelled in wax and the pouring channels and risers, also in wax, attached. This is of beeswax mixed with the resin of the sila tree and a little vegetable oil, the proportions depending on the season in these lands of cold winters. In winter one dhari $(2.4 \mathrm{~kg})$ requires only one pau (200 gm) of resin to stiffen it, but in summer 1.5 pau are required. The completed model is moulded with clay. For the first layers fine clay mixed with filtered cow dung in the form of a slurry into which the model is dipped and then allowed to dry. This is repeated two or three times. Then a coarser clay, containing sand as well as rocky fragments and tempered with rice husk, is applied, again in layers allowing time for slow drying, increasing the proportion of clay, so that the final layer has about three parts clay to one part husk. Alsop and Charlton (1973) claimed that the total time for the layers of clay to dry could extend to several months, however Lo Bue's (1981) more carefully timed observations showed that the moulding took nine days in total, which seems more realistic.

After drying the moulds are heated to remove the wax and then baked to red heat in the upper chamber of the furnace in which the metal

\footnotetext{
${ }^{22}$ The presence of lead, and to a lesser extent tin and zinc in the copper alloy can ruin a mercury-gilt surface by entering into the amalgam when it is heated to drive off the mercury, and thus copper was preferred where mercury gilding was intended. Mercury gilding was used in Nepal until quite recently (Gajurel and Vaidya, 1984, pp.54-7; Oddy et al., 1981), but has now been replaced by electro-gilding.
} 
was being melted in crucibles in the lower, hotter, chamber.

Hollow castings were, and remain, more common especially for the larger figures. As Krishnan (1976, p.32) notes, the north of India cast separate hollow components in contrast to the south of India which favoured solid single castings.

For hollow casting the wax has to surround a clay core. In the Himalayas two quite distinct methods of hollow lost wax casting evolved. There is the standard method in which a wax coating was applied to a clay core (Fig. 23a). Reedy's scientific studies on Himalayan hollow cast images ranging in date over the last thousand years (summarised in Reedy 1997, pp.110-123) have shown that the core refractories are rather coarse and sandy clays. Organic material is common and likely to come from material such as rice husks, cloth and dung as specified in both the early recipes and current practice, and could account for up to $30-40 \%$ of the volume of the core. Silica, usually in the form of sand, usually accounts for between 10 to $30 \%$ together with some plagioclase feldspars, including micas such as chlorite, muscovite and biotite. Crushed calcite or other carbonate minerals were sometimes added as temper. The core was covered in wax sheets and the modelling and casting proceeded as with the solid castings.

The Newari of Nepal also employ an alternative and apparently unique method of making the model using sheets of wax (de Labriffe, 1973; Alsop and Charlton, 1973; Lo Bue, 1981 and the present author's observations made in Patan in 1987). The sheets of wax are prepared by beating out a cake of wax followed by rolling into sheets of uniform thickness ${ }^{23}$. The warm and softened wax sheets are then bent round into cylindrical shapes (Fig. 24) and moulded to form

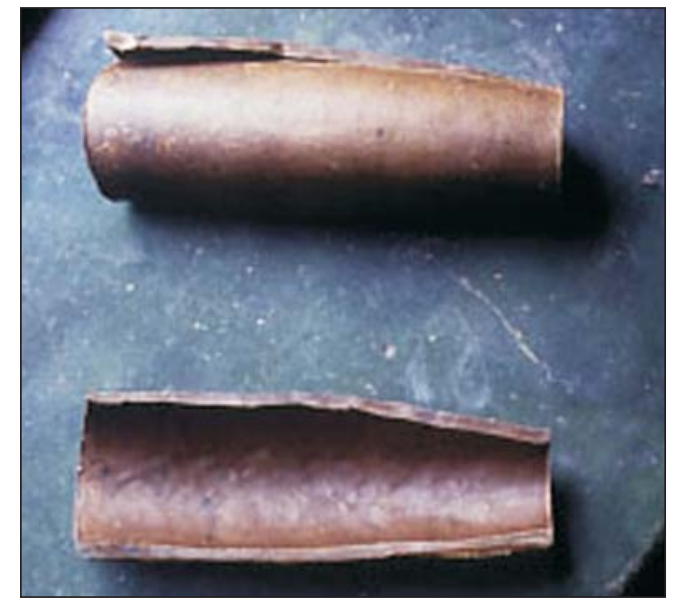

Fig. 24. Two sections of wax shaped by different processes, direct and indirect moulding. The upper sheet has been bent directly into a cylinder by hand, and there is just the one seam; the lower piece has been moulded indirectly by pressing the wax into a negative mould and to complete the cylinder another piece will be required leaving two seams when joined. Patan. (P. Craddock, 1987)

the limbs, torso, etc of the figure (Fig. 25). These can either then be united with wax to wax joins sealed with molten wax and invested, or more usually, each cylinder is invested and cast separately (Fig. 26).

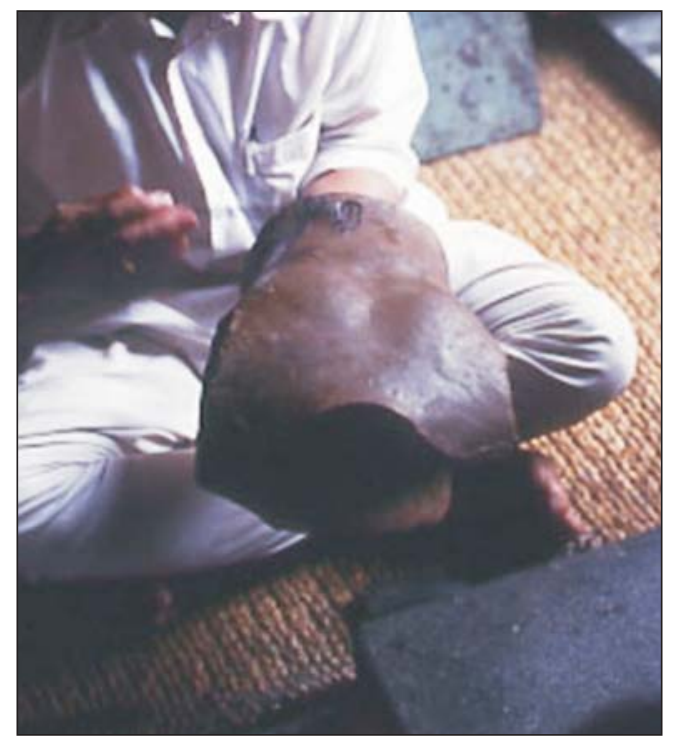

Fig. 25. Shaping the wax torso of a large statuette by the direct process, note the core has not yet been added.

\footnotetext{
${ }^{23}$ The thickness depends on the metal to be cast, sluggish and viscous molten copper requires a considerably thicker mould space to flow satisfactorily than the more mobile molten brass.
} 


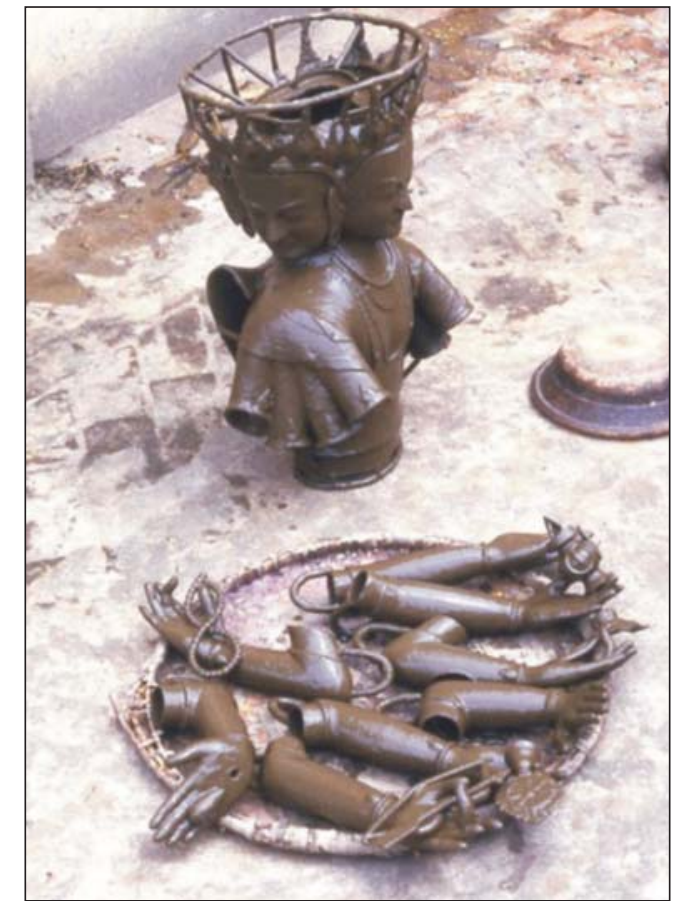

Fig. 26. Wax upper torso and head of a figure and the numerous arms that will only be attached after casting.

The runners and risers added (Fig. 27) and the wax is invested by dipping it in a thin slurry of fine clay (the composition as described above) (Fig. 28) both inside and out, dried and more thin layers applied. Thicker, stiff core clay can then be applied to the thin moulding clay adhering to the inner surface of the wax, and if necessary a hole could be cut in the wax to gain access to the interior and add more clay to form a more substantial core (NB there is no need for the core to be solid, it

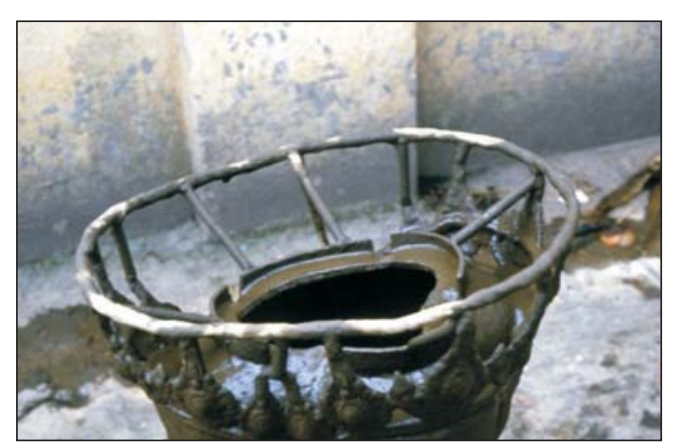

Fig. 27. Wax head with the pouring channels and risers attached.

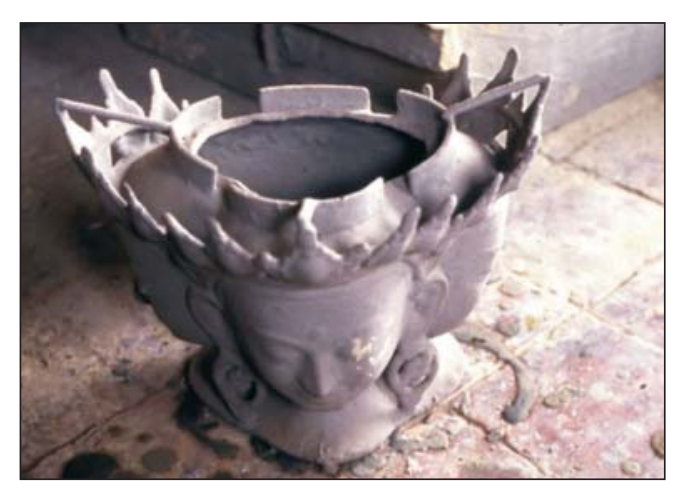

Fig. 28. Wax head of deity after the application of the first layer of moulding clay by dipping. Note this covers the whole mould including the inside before the core is added.

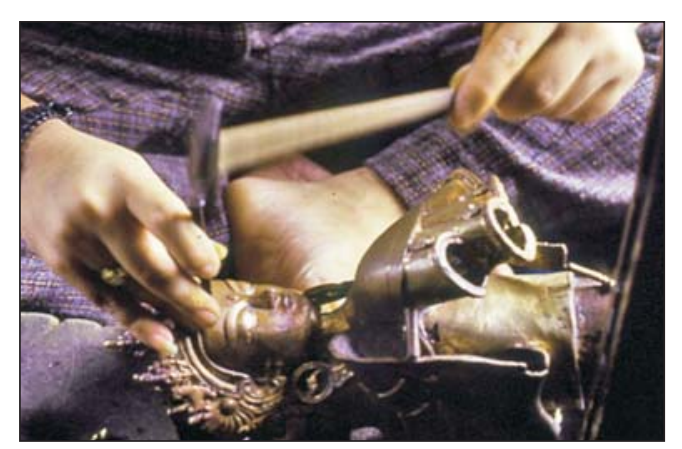

Fig. 29. Details of the casting are being sharpened and emphasised by chasing, note the selection of tracers and chisels (see also Fig. 30)

could just form a substantial cylinder). The drying, melting and casting are then much as described above. Afterwards the casting is worked to repair damage, consolidate and sharpen the surface (Fig. 29) and commence polishing (Fig. 30). The components are then joined by soldering, riveting or simply peening. Arms and torsos, for example, are often joined at the shoulder by dovetail joins so placed that they could be subsequently hidden beneath applied bracelets etc. The history of the wax sheet method is uncertain, it is not recent and de Labriffe suggested it came to the Himalayas from north and east India in the $11^{\text {th }}$ century by smiths escaping the Islamic onslaught, and so could represent the earlier Gupta and Gandharan casting traditions, themselves having strong Hellenistic influences. 


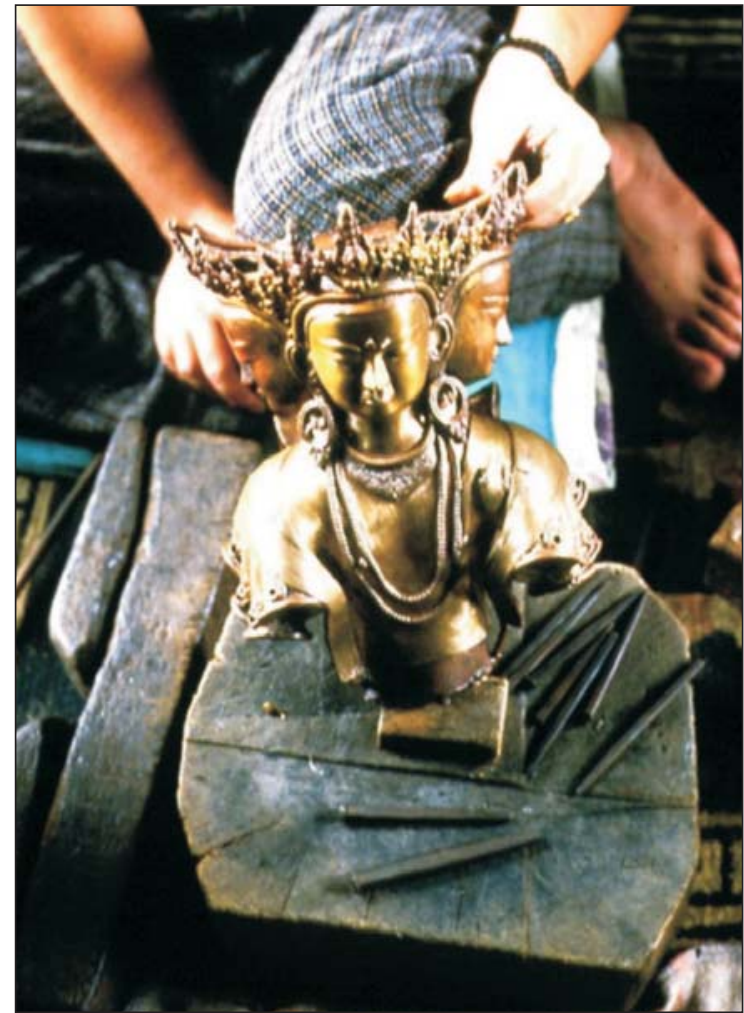

Fig. 30. Casting after chasing, scrapping and burnishing, but before assembly and final polishing.

This is clearly a direct lost wax process, but it can also be adapted as an indirect method (Fig. 23b) if several copies are required and also as an insurance against failure. In the indirect process the wax original is impressed into a hard wax (containing more resin), suitably softened by heat, and wetted with water to act as a release, to make a negative wax piece mould, known as a das or thāsā. Alternatively clay can be used to form the das, interestingly plaster of Paris, the usual medium for creating the negative mould in the West (Mills and Gillespie, 1969), never seems to have been used. ${ }^{24}$ For many Newari smiths, especially those catering for tourists, little direct process free modelling is done, instead figures are moulded from a limited range of negative moulds, this is a true indirect lost wax casting process. ${ }^{25}$

Gajurel and Vaidya (1984, pp.41-8) describe a similar process where relatively simple copper alloy vessels are made in sections by an indirect lost wax process. For a bowl the wax sheets are pressed onto the clay or even metal negative mould or former to create one half of the bowl, this is then repeated to form the other half. The two halves are then joined with molten wax and turned on a lathe to smooth them prior to investing and casting. To make a more complex vessel, with a base for example, there can be two negative moulds so that now there are two top half sections and two lower half sections. All of these are then joined and smoothed as before. Complex decoration can be produced by adding wax details to the finished wax body of the vessel. The wax is then invested and cast as with other Nepalese traditional castings. One wonders if the Harappan cast copper alloy vessels (see above and endnote 4) were made in a similar way.

\section{INFLUENCES, INTERACTIONS AND INFERENCES}

The techniques by which the civilisations of the Mediterranean civilisations of antiquity cast their major bronzes has been the subject of sustained interest and changing opinion for well over a century, and still lacks agreement on many key issues. In part this is due to the relative paucity of evidence, certainly when compared to South Asia. Written evidence is meagre, and largely secondary, certainly with nothing like the direct instruction contained in the Silpaśāstras. Figurative information is limited to some Egyptian wall paintings such as those on the tomb of RekhMi-Re (Davies 1943), which can be surprisingly

\footnotetext{
${ }^{24}$ Is this why plaster of Paris is so rarely encountered in Greek and Roman foundry debris (Schneider and Zimmer 1986, Schneider 1989)?

${ }^{25}$ Differentiating between castings made by the two methods could be very difficult. Viewed from the inside where the joins are unlikely to have been carefully smoothed, the direct process wax cylinder should have only one seam where it was bent over and joined, whereas the indirect wax sections should have at least two where each component was joined (Fig. 24).
} 
detailed, and the enigmatic scenes of metalworking depicted on some Greek vases (Oddy and Swaddling, 1985) ${ }^{26}$.

Some Greek foundries where large bronze statues were cast have been excavated (Schneider, 1989; Heilmeyer et al., 1987; Zimmer, 1990), the principal features being the pits in which the statues are likely to have been cast together with the remains of hearths and fragments of crucibles and moulds (Schneider and Zimmer, 1986). The other main evidence of the casting processes are the surviving statues themselves. At the end of Classical Antiquity in the mid first millennium AD the large scale production of statuary severely declined and in most regions that were once part of the Roman Empire ceased altogether. In the absence of good descriptions of the original casting processes, when the casting large statues began about 1,000 years later in the European Renaissance, the technology had to re-invented. When interest in the technology of the ancients was kindled from the $18^{\text {th }}$ century onwards the current practitioners were (and still are) consulted, and having examined the particular antiquity would usually, and understandably, report based on how they would make it now, often with such evidence as was still visible on the casting itself ignored or misinterpreted.

Thus many of our changing perceptions of how the ancient castings were made are more often related to current practice than the actual evidence. In this situation study of the South Asian evidence can offer interesting and sometimes disquieting insights. Some of these will be considered here, commencing with the melting and pouring of the metal.

It is currently believed that the main torso of the statue was cast standing upright in the casting pits by pouring in the molten metal from crucibles. With some castings weighing several hundred kilos and the maximum capacity of a crucible in antiquity being about a kg, this does raise serious doubts about the viability of the method. For example, the bronze ram from the prow of a Hellenistic warship, found at Athlit, off the coast of Israel, weighing about $500 \mathrm{~kg}$ (which together with runners, risers and sprues would have required about $1,000 \mathrm{~kg}$ of metal). This was first published as a sand casting (Casson and Steffy eds., 1991), and latterly as a lost wax casting (Oron, 2006). Neither study produced convincing evidence, but both assumed the metal was poured from crucibles without appreciating this would have entailed approximately 1,000 separate pouring made in very rapid succession, or trying to visualise how it could have been achieved. The earliest European description of casting heavy items does suggest melting the metal in the furnace and running it directly into the mould as an alternative to crucible pouring. This is the account given in the On Divers Arts of Theophilus (Hawthorne and Smith, 1963), but it only dates from the $12^{\text {th }}$ century AD, although it is the earliest Western account of the casting process ${ }^{27}$.

Hoffmann and Konstam (2002) proposed that in fact the classical smiths were running the metal directly from furnaces such as those depicted on the Greek vases (see footnote 26).

\footnotetext{
${ }^{26}$ These mainly depict workshops where bronze statues are being produced. They all feature a tall shaft furnace of the type that is believed would have been used for primary smelting metals, not suitable for crucible melting. Furthermore they are all shown with a large pot sat on top which would seemingly rule out their function as a shaft furnace. No casting pits, moulds or crucible pouring are shown, only some hammering operations, often surrounded by big sections of statuary, which are the only evidence that these scenes depict foundries. Hoffmann and Konstam (2002) suggest that the furnaces are the chimneys of cupolas for direct melting of the metal.

${ }^{27}$ Similarly in South Asia the earliest descriptions of running the metal directly from the furnace to the mould is in the dramatic account of the casting of a large bombard in the $16^{\text {th }}$ century given in the Bābur-nāma (endnote 7), the earlier Śilpaśāstra accounts mention only crucible pouring.
} 
Unfortunately for their arguments nothing resembling a casting pit is depicted on the vases, and the excavated casting pits have no evidence for channels leading the molten metal from the putative furnace to the mould. Interestingly, they also propose that the moulds instead of standing vertically in the pits, lay at an angle of about $45^{\circ}$ along the sloping side of the pits that contained the steps down. This conjecture was made apparently without knowledge that casting at an angle was and is the usual method adopted in South Asia, as described above (Fig. 17). However their reconstruction still had the metal running into the top and cascading down through the mould, rather than entering at a lower point and rising and filling the mould in an orderly fashion. The present author discussed this with the sthapati of Swamimalli who were unanimous that top pouring into a vertical mould would not work.

After long debate it is currently generally agreed that the major statuary castings in the western world are likely to have been lost wax castings, discarding earlier ideas on sand casting or piece moulding that were current in the first half of the $20^{\text {th }}$ century (Kluge, 1927, etc). However there is still considerable disagreement over whether the major hollow lost wax castings were made by the direct or indirect process (Fig. 23). A variety of evidences have been advanced, based on examination of the surviving bronzes, and here the current South Asian practice can throw considerable light on their interpretation.

It is claimed that the indirect process castings are of much more uniform thickness than the direct castings. This is because it easier to apply a uniform thickness of wax to the negative mould, than with the direct process where the wax was applied to the core before modelling. However the tribal casters of South Asia currently achieve quite remarkable uniform thin wax layers (typically 1/16 inch, [2 mm] as described by Reeves, 1962) by winding wires or strips of wax around the cores in their direct casting methods.
This is not to argue that this must have been the method used in antiquity where uniform thickness has been achieved, but rather to observe that there is a viable alternative method currently in use, but not considered because it is beyond the experience or practice of European experts from the Medieval period on.

The main evidence for the indirect process is that the mould was built up in sections. With a direct hollow casting it is argued that the wax would have been applied to the core and there would be no join lines. For an indirect hollow casting a plaster negative mould is made around the original work piece, following current practice (Mills and Gillespie, 1969). The plaster mould must be in sections so that it can be taken apart and the original removed. Then it is usual practice to press the wax sheet into the negative mould sections, creating positive wax sections. These are then assembled and held together with molten wax. The join lines on the outside will invariably have been removed, but there was no need to do that on the inside and so the join lines and dribbles of molten wax will have been preserved in the mould and will be reproduced in the metal of the final casting. Thus the presence of these join lines and dribbles on the inside surfaces of ancient statuary are taken as incontrovertible evidence of the indirect process (Haynes, 1992, for example).

However, the Newari smiths of present day Nepal use a direct process, bending sheets of warmed wax to form the various components of their hollow sculptures as described above and Figs. 24-30. As with the European indirect process the core is only added after the wax has been modelled. It could be very difficult to determine whether a hollow figure was an indirect (European) or a direct Newari casting (but see Fig. 24). The problems are further complicated by the Newari actually also taking negative moulds from their wax positives, such that nowadays the two processes, direct and indirect, are practised side by side. The history of the Newari process is 
uncertain, none of the Silpaśāstras mention the technique, although hollow lost wax casting in general is poorly covered (see above). The technique is unknown in China or South East Asia. De Labriffe (1973) suggested that the process was of Indian origin and had been brought to the Himalayas by smiths from India fleeing the Moslem invasions in the $11^{\text {th }}$ century AD. They worked in the tradition of the Gupta, and further back, the Gandharan smiths. Given the strong Hellenisitc influence on the Gandharan sculpture, if an outside influence has to be found for this technique, could it be from the Greek and Mediterranean world where such hollow castings are now automatically classed as being made by the indirect process?

\section{BIBLIOGRAPHY}

Agrawal, D.P. Ancient Metal Technology and Archaeology of South Asia, Aryan Books, New Delhi, 2000

Alsop, I. and Charlton, J. Image casting in Oku Bahal. Journal of the Institute of Nepal and Asian Studies, 1.1 (1973):22-49

Balasubramaniam, R. The Saga of Indian Cannons, Aryan Books, New Delhi, 2008

Beer de, C. ed. The Art of Gunfounding, Jean Boudriot, Rotherfield, Sussex, UK, 1991.

Beveridge, A.S. The Bābur-nāma in English, Luzac, London, 1969

Bhardwaj, H.C and Sharma, V.L. Technology, Tools and Appliances, Shilpi Publications, Allahabad, 1997

Bhowmik, S.K. and Jani, M. Literary references on metals, metallic objects of art and metal technology. Archaeometallurgy in India, V. Tripathi ed. Sharada Publishing House, Delhi, 1998, pp.319-28

Casson, L. and Steffy, J.R. eds. The Athlit Ram, Texas A \& M University, College Station, Texas, 1991

Chakrabarti, D.K. and Lahiri, N. Copper and its Alloys in Ancient India, Munshiram Manoharlal, New Delhi, 1996

Chattopadhyay, P.K., Archaeometallurgy in India, Kashi Prasad Jayaswal Research Institute, Patna, 2004

Craddock, P.T. The copper alloys of Tibet and their background. Oddy and Zwalf (eds.) (1981): 1-32
Craddock, P.T. Three thousand years of copper alloys: From Bronze Age to the Industrial Revolution. Application of Science in Examination of Works of Art, P.A. England and L. van Zelst (eds.), Museum of Fine Art, Boston Ma., 1985, pp.211-71

Craddock, P.T. Cast iron: The elusive feedstock of crucible steel. Indian Journal of History of Science, 42.2 (2007): 593-607

Craddock, P.T. Refractories with a purpose II: Ceramics for casting. The Old Potter's Almanack,19.1 (2014): 117

Craddock, P.T. and Meeks, N.D. Iron in ancient Copper. Archaeometry 29.2 (1987): 187-204

Craddock, P.T. and Hook, D.R. The Bronze Industries of South India: A Continuing Tradition? Scientific Research on the Sculptural Arts of Asia, J.G. Douglas, P. Jett \& J. Winter (eds.). Freer Gallery of Art, Washington DC (2007): 75-89

Craddock, P.T., Cartwright, C., Eckstein, K., Freestone, I., Gurjar, L., Hook, D., Middleton, A. and Willies, L. Simple Sophistication: Mauryan silver production in north west India. British Museum Technical Bulletin, 7 (2013): 79-93

Craddock, P.T., Gale, N.H., Cribb, J. and Gurjar L.K. The sources of zinc in early India: The evidence of numismatics, trade and lead isotope analysis. Proceedings of the BUMA 7 conference, A. Giumlia Mair and S. Ranganathan (eds.), forthcoming, pp.13947

Dagyab, L.S. Tibetan Religious Art: Part 1 Texts, Otto Harrassowitz, Wiesbaden,1977

Davey, C.J. The early history of lost wax casting. Metallurgy and Civilisation, J. Mei and Th. Rehren eds. Archetype, London, (2009): 147-154

Davies, N. de G. The Tomb of Rekh-Mi-Re at Thebes, Metropolitan Museum of Art, New York, 1943

Dubrovin, A.F. Tibetan Buddhist Statuary Alloys. Bulletin of the Metals Museum of the Japan Institute of Metal,15 (1990): 45-77

Dubrovin, A.F. Tibetan Statuary Alloys (Part II): Some Possibilities for Dating and Attributing According to Minor Elements Content. Bulletin of the Metals Museum of the Japan Institute of Metals, 17 (1992): 15-31

Elphick, G. The Craft of the Bellfounder, Phillimore, Chichester, 1988 
Freestone, I.C. and Tite, M.S. Refractories in the Ancient and Preindustrial World. High-Technology Ceramics Past, Present and Future. Ceramics and Civilisation III, W.D. Kingery (ed.). American Ceramic Society, Westerville, Ohio (1986): 35-64

Gairola, T.R. Bīdrī ware. Ancient India, 12 (1956): 116-118

Gajurel, C.L. and Vaidya, K.K., Traditional Arts and Crafts of Nepal, S. Chand, New Delhi, 1984

Hauptmann, A. Chemical Analysis of Prehistoric Metal Artefacts from the Indian Subcontinent, Appendix 1, Yule (1989): 261-67

Hawthorne, J.G. and Smith, C.S. trans. and edit. On Divers Arts: The Treatise of Theophilus, University of Chicago, Chicago, 1963

Haynes, D. The Technique of Greek Statuary Bronze. Philipp von Zabern, Mainz, 1992

Heilmeyer, W-D., Zimmer, G. and Schneider, G. Die Bronzegiesserei unter der Werkstatt des Phidas in Olympia. Archäologischer Anzeiger. (1987): 239-299

Hegde, K.T.M. Analytical study of Paunar coins. Journal of the Numismatic Society of India, 37.1-2 (1975): 18083

Hoffmann, H. and Konstam, N. Casting the Riace Bronzes: Modern Assumptions and Modern Facts. Oxford Journal of Archaeology, 21.2 (2002): 153-166

Horne, L. The Brass casters of Dariapur, West Bengal: Artisans in a changing world. Expedition, 29 (1987): 39-46

Hughes, M.J. Atomic absorption analysis of Indian Copper Hoard implements in the British Museum collections, Appendix 2, Yule (1989): 267-269

Hunt, L.B. The long history of lost wax casting. Gold Bulletin, 13.2 (1980):63-79

Jackson, V.H. ed., An Account of the District of Purnea in 1809-1810 by Francis Buchanan, Bihar and Orissa Research Society, Patna, Bihar, 1928

Johnson, B. B. Krishna Rājamannār bronzes: An examination and treatment report. Krishna: The Cowherd King, P. Pal. Los Angeles County Museum of Art Monograph Series 1, Los Angeles, 1972

Kenoyer, J.M. and Miller, H. M.-L. Metal Technologies of the Indus Valley Tradition in Pakistan and Western India. The Archaeometallurgy of the Asian Old World, V.C. Pigott (ed.), MASCA Research Paper, University of Pennsylvania Museum, Philadelphia, 16 (1999): 107-151
Kluge, K. Die antiken Grossbronzen I: Die antike Erzgestaltung, W. de Gruyter, Berlin, 1927

Krishnan, M.V. Cire Perdue Casting in India, Kanak Publications, New Delhi, 1976

Kuppuram, G. Ancient Indian Mining, Metallurgy and Metal Industries, Sundeep Prakashan, Delhi,1989

Labriffe, de M-L. Etude de la fabrication d'une statue au Nepal. Kailash, 1.3 (1973): 185-92

Lal, B.B. An examination of some metal images from Nālānda. Ancient India, 12 (1956): 53-57

Lal, K. National Museum Collection: Bidri Ware, National Museum, New Delhi, 1990

La Niece, S. Medieval Islamic Metal Technology. Scientific Research in the Field of Asian Art, P. Jett (ed.). Freer Gallery of Art, Washington DC (2003): 90-96

La Niece, S. and Martin, G. The technical examination of bidri ware. Studies in Conservation, 32.3 (1987): 97101

Levy, T.E., Levy, A.M., Sthapathy, D., Sthapathy, S. and Sthapathy, S., Masters of Fire: Hereditary Bronze Casters of South India, Deutsches Bergbau Museum, Bochum, 2008

Lo Boe, E. Casting of devotional images in the Himalayas. Aspects of Tibetan Metallurgy, W.A. Oddy and W. Zwalf eds. British Museum Occasional Paper, London, 15 (1981): 69-80

Mehta, R.J. The Handicrafts and Industrial Arts of India, D.B. Taraporevala and Sons, Bombay, 1960

Mille, B., Bessenval, R. and Bourgarit, D. Early 'lost-wax casting' in Balochistan (Pakistan): the "Leopards Weight “ from Shahi-Tump. Persiens antike Pracht, Bergbau-Handwerk-Archäologie, T. Stöllner, R. Slotta and A. Vatandoust (eds). Der Anschnitt Beiheft 12: Deutsches Bergbau Museum, Bochum (2004): 274280

Mills, J.W. and Gillespie, M., Studio Bronze casting - Lost Wax, Maclaren and Sons, London, 1969

Mukherjee, B.N. and Lee, P.K.D. Technology of Indian Coinage, Indian Museum, Calcutta, 1988

Mukherjee, M. Metal Craftsmen of India, Anthropological Survey of India, Calcutta, 1978

Mukharji, T.N. Bidriware. Journal of Indian Arts and Industry, 13 (1886):41-44

Nambiar, P.K. ed. Census of India 1961 - Handicrafts and Artisans of Madras State- Icons in Stone and Metal, Census of India, Madras, 1964. 
Neogi, P. Copper in Ancient India, IACS, Calcutta, 1917 (republished 1979, Janaki Prakashan, New Delhi and Patna).

Nieuwenhuysen, P. and Adams, F. Elemental analysis of Himalayan metal statues. Journal of the Historical Metallurgy Society, 18.2 (1984): 105-08

Oddy, W.A., Bimson, M. and La Niece, S. Gilding Himalayan images: history, tradition and modern techniques, Oddy and Zwalf (eds.) (1981): 87-102

Oddy, W.A. and Zwalf, W., (eds.) Aspects of Tibetan Metallurgy, British Museum Occasional Paper, London, 15 (1981)

Oddy, W.A. and Swaddling, J. Illustrations of Metalworking Furnaces on Greek Vases. Furnaces and Smelting Technology in Antiquity, P.T. Craddock and M.J. Hughes eds. London, British Museum Occasional paper, 48 (1985): 43-58

Oron, A. The Athlit ram bronze casting reconsidered: scientific and technical re-examination. Journal of Archaeological Science, 33.1 (2006): 63-76

Pal, P. Bronzes of Kashmir, Munshiram Manohaval, New Delhi, 1976

Prakash, B. Ancient shell-molding technology and casting of batloi. Abstract in Proceedings of the Fourth International Conference of the Beginning and Use of Metals and Alloys (BUMA IV), BUMA Organising Committee. Japan Institute of Metals, Sendai (1998): 247-248

Prakash, S. and Rawat, N.S. Chemical Study of Some Indian Archaeological Antiquities, Uttar Pradesh State Council of Scientific and Industrial Research Monograph, Asia Publishing House, Bombay,10 (1965)

Reedy, C.L. Modern statues and traditional methods: a casting workshop in Himachal Pradesh Expedition, 29. 3 (1987): 47-54

Reedy, C.L. Petrographic analyses of casting core materials for provenance studies of copper alloy sculpture. Archaeomaterials, 5 (1991): 121-63

Reedy, C.L. The Materials and Technology of Gandharan and Related Copper-based Sculptures. The Crossroads of Asia: Transformation in Image and Symbol, E. Errington, J. Cribb and M. Claringbull (eds.), The Ancient India and Iran Trust. Cambridge (1992): 24155

Reedy, C.L. Himalayan Bronzes: Technology, Style and Choices, University of Delaware Press, Newark and Associated Universities Press, London, 1997
Reedy, C.L. New Evidence for the Historical Context of Buddhist Bronzes from Swat Valley, Northern Pakistan. Scientific Research in the Field of Asian Art, P. Jett (ed.). Freer Gallery of Art, Washington DC (2003): 133-139

Reedy, C.L. and Harlacher, S. Elemental Composition of Sri Lankan Bronzes. Scientific Research on the Sculptural Arts of Asia, J.G. Douglas, P. Jett \& J. Winter (eds.). Freer Gallery of Art, Washington DC (2007): 63-74

Reeves, R. Cire perdu casting in India, Crafts Museum, New Delhi, 1962

Riederer, J. Zur metallanalyse der Statuetten. Das Bild des Buddha, H. Uhlig (ed.), Kunstamt Tempelhof, Berlin (1979): 63-68

Riederer, J. Materialanalysen an Bronze-und Messingstatuetten des Staatlichen Museums für Völkerkunde in München.. Skulpturen aus Indien: bedeutung und Form, C. Mallebre (ed.), Staatliches Museum für Völkerkund, Munich (1984): 231-236

Riederer, J. Metal analyses of Indian bronze sculptures Journal of Archaeological Chemistry, 3 (1985): 6972

Riederer, J. Zu Metallanalysen der Kultstatuetten. Die Götter des Himalaya, G.W. Essen \& Tsering Tashi Thingo, Prestel Verlag, Munich (1989): 292-296

Riederer, J. The Relation between the Composition of North Indian Statuettes of Copper Alloys and the Region and Date of their Origin. Role of Chemistry in Archaeology, M.C. Ganorkar and N. Rama Rao (eds.), Birla Institute, Hyderabad (1991): 95-102

Sahni, B. The Technique of Casting Coins in Ancient India, Memoir 1 of the Numismatic Society of India, Bombay, 1945

Sali, S.A., Daimabad, 1976-9, Archaeological Survey of India, Delhi, 1986

Schneider, G. Bronze casting at Olympia in Classical times. MASCA Research Paper in Archaeology, 6 (1989): 1724

Schneider, G. and Zimmer, G. Technische Keramik aus antiken Bronzegußwerksttäten in Olympia und Athen. Berliner Beiträge zur Archäometrie, 9 (1986):17-60

Sharma, V.J. and Bharadwaj, H.C. Use of crucibles in ancient India. Journal of Arcahaeological Chemistry, 4 (1986): 43-52 
Skibo, J.M., Schiffer, M.B. and Reid, K.C. Organictempered pottery: an experimental study. American Antiquity, 54 (1989): 122-46

Smith, C.S. and Gnudi, M.T. [trans. and eds.], The Pirotechnia of Vannoccio Biringuccio, Basic Books, Chicago, 1942

Srinivasan, S. and Glover, I. Wrought and quenched, and cast high-tin bronzes in Kerala State, India. Journal of the Historical Metallurgy Society, 29.2 (1995): 6988

Stronge, S. Bidri Ware, Victoria and Albert Museum, London, 1985

Swarnakamal, Bhowmik, S.K. Studies in Metallic Art and Technology of Gujarat, Museum and Picture Gallery, Baroda, 1980

Untracht, O. Metal Techniques for Craftsmen, Doubleday, London, 1968

Werner. O. Spektralanalytische und Metallurgische Untersuchungen an Indischen Bronzen, Brill, Leiden, 1972
Venkatraman, B., Babu Rao, C., Bhattacharya, D.K. and Raj, B. Radiography of medieval investment-cast idols of India. British Journal of Non-Destructive Testing, 35.10 (1993): 557-561

Yazdami, G. Bidar: Its History and Monuments, Motilal Banarsidass, Delhi, 1995

Yule, P. On the Function of the Prehistoric Copper Hoards of the Indian Subcontinent. South Asian Archaeology 1983, eds. J. Schotsmans and M. Taddei, Istituto Universitario Orientale, Naples (1985): 495-508

Yule, P. The Copper Hoards of the Indian Subcontinent: Preliminaries for an Interpretation. Jahrbuch des Römisch Germanischen Zentralmuseums Mainz, 36 (1989): 193-275

Yule, P. The Copper Hoards of Northern India. Expedition, 39.1 (1997): 22-32

Zhou, W. Coin-casting technologies and their evolution in ancient China. Bulletin of the Metals Museum of the Metals Society of Japan, 37 (2003): 3-21

Zimmer, G. Griechische Bronzegusswerkstätten, Mainz, Philipp von Zabern, 1990 